NBER WORKING PAPER SERIES

\title{
UNWILLING OR UNABLE TO CHEAT? EVIDENCE FROM A RANDOMIZED TAX AUDIT EXPERIMENT IN DENMARK
}

\author{
Henrik J. Kleven \\ Martin B. Knudsen \\ Claus T. Kreiner \\ Søren Pedersen \\ Emmanuel Saez \\ Working Paper 15769 \\ http://www.nber.org/papers/w15769 \\ NATIONAL BUREAU OF ECONOMIC RESEARCH \\ 1050 Massachusetts Avenue \\ Cambridge, MA 02138 \\ February 2010
}

\begin{abstract}
We are grateful to Jakob Egholt Sogaard for outstanding research assistance. We thank Oriana Bandiera, Richard Blundell, Raj Chetty, John Friedman, William Gentry, Wojciech Kopczuk, Monica Singhal, Joel Slemrod, and numerous seminar participants for comments and discussions. Financial support from ESRC Grant RES-000-22-3241, NSF Grant SES-0850631, and a grant from the Economic Policy Research Network (EPRN) is gratefully acknowledged. The responsibility for all interpretations and conclusions expressed in this paper lie solely with the authors and do not necessarily represent the views of the Danish tax administration (SKAT), the Danish government, or the National Bureau of Economic Research.
\end{abstract}

NBER working papers are circulated for discussion and comment purposes. They have not been peerreviewed or been subject to the review by the NBER Board of Directors that accompanies official NBER publications.

(C) 2010 by Henrik J. Kleven, Martin B. Knudsen, Claus T. Kreiner, Søren Pedersen, and Emmanuel Saez. All rights reserved. Short sections of text, not to exceed two paragraphs, may be quoted without explicit permission provided that full credit, including $\odot$ notice, is given to the source. 
Unwilling or Unable to Cheat? Evidence from a Randomized Tax Audit Experiment in Denmark Henrik J. Kleven, Martin B. Knudsen, Claus T. Kreiner, Søren Pedersen, and Emmanuel Saez NBER Working Paper No. 15769

February 2010

JEL No. H3

\begin{abstract}
This paper analyzes a randomized tax enforcement experiment in Denmark. In the base year, a stratified and representative sample of over 40,000 individual income tax filers was selected for the experiment. Half of the tax filers were randomly selected to be thoroughly audited, while the rest were deliberately not audited. The following year, "threat-of-audit" letters were randomly assigned and sent to tax filers in both groups. Using comprehensive administrative tax data, we present four main findings. First, we find that the tax evasion rate is very small $(0.3 \%)$ for income subject to third-party reporting, but substantial (37\%) for self-reported income. Since $95 \%$ of all income is third-party reported, the overall evasion rate is very modest. Second, using bunching evidence around large and salient kink points of the nonlinear income tax schedule, we find that marginal tax rates have a positive impact on tax evasion, but that this effect is small in comparison to avoidance responses. Third, we find that prior audits substantially increase self-reported income, implying that individuals update their beliefs about detection probability based on experiencing an audit. Fourth, threat-of-audit letters also have a significant effect on self-reported income, and the size of this effect depends positively on the audit probability expressed in the letter. All these empirical results can be explained by extending the standard model of (rational) tax evasion to allow for the key distinction between self-reported and third-party reported incomes.
\end{abstract}

Henrik J. Kleven

Department of Economics \& STICERD

LSE

Houghton Street

London WC2A 2AE

United Kingdom

H.J.kleven@1se.ac.uk

Martin B. Knudsen

Danish Inland Revenue

Copenhagen

Denmark

martin.knudsen@skat.dk

Claus T. Kreiner

Institute of Economics

University of Copenhagen

Studiestraede 6

DK-1455 Copenhagen K

Denmark

claus.thustrup.kreiner@econ.ku.dk

\author{
Søren Pedersen \\ Danish Inland Revenue \\ Copenhagen \\ Denmark \\ Soren.Pedersen@skat.dk \\ Emmanuel Saez \\ Department of Economics \\ University of California, Berkeley \\ 549 Evans Hall \#3880 \\ Berkeley, CA 94720 \\ and NBER \\ saez@econ.berkeley.edu
}




\section{Introduction}

An extensive literature has studied tax evasion and tax enforcement from both the theoretical and empirical perspective. The theoretical literature follows on the work of Allingham and Sandmo (1972), which builds on the Becker (1968) theory of crime and focuses on a situation where a taxpayer decides how much income to report to the government facing a probability of audit and a penalty for cheating. Under low audit probabilities and low penalties, the expected return to evasion is high and the model then predicts substantial noncompliance. However, it has been argued that this prediction is in stark contrast with the observation that compliance levels are high in modern tax systems despite low audit rates and fairly modest penalties. ${ }^{1}$ This suggests that the standard economic model misses important aspects of the real-world reporting environment. In particular, many have argued that observed compliance levels can only be explained by psychological or cultural aspects of tax compliance such as social norms, tax morale, patriotism, guilt and shame. ${ }^{2}$ In other words, taxpayers, despite being able to cheat, are unwilling to do so for non-economic reasons.

While psychology and culture may be important in the decision to evade taxes, the standard economic model deviates from the real world in another potentially important aspect: it focuses on a situation with pure self-reporting. By contrast, all advanced economies make extensive use of third-party information reporting whereby institutions such as employers, banks, investment funds, and pension funds report taxable income earned by individuals (employees or clients) directly to the government. As pointed out by Slemrod (2007), under third-party reporting, the observed audit rate is a poor proxy for the probability of detection faced by a taxpayer contemplating to engage in tax evasion, because systematic matching of information reports to income tax returns will uncover any discrepancy between the two. Thus, taxpayers with only third-party reported income may be unable to cheat on their taxes. Empirically, the U.S. Taxpayer Compliance Measurement Program (TCMP) has documented that aggregate compliance is much higher for income categories with substantial information reporting than for income

\footnotetext{
${ }^{1}$ Andreoni, Erard, and Feinstein (1998) conclude at the end of their influential survey that "the most significant discrepancy that has been documented between the standard economic model of compliance and real-world compliance behavior is that the theoretical model greatly over-predicts noncompliance."

${ }^{2}$ Studies advocating the importance of behavioral, psychological, or cultural aspects of tax evasion include Alm, McClelland, and Schulze (1992), Andreoni, Erard, and Feinstein (1998), Cowell (1990), and Feld and Frey (2002, 2006). A recent randomized experiment analyzed by Blumenthal, Christian, and Slemrod (2001), however, found that normative appeals to social norms and equity had no effect on compliance behavior.
} 
categories with little or no information reporting (Internal Revenue Service, 1996, 2006).

A large body of empirical work, surveyed by Andreoni, Erard, and Feinstein (1998) and Slemrod and Yitzhaki (2002), has tried to test other aspects of the standard model, in particular the effects of audit probabilities and marginal tax rates on tax evasion. These effects are central to tax policy and tax enforcement design. Most of the literature relies on observational and non-experimental data, which creates serious measurement and identification issues, ${ }^{3}$ or on laboratory experiments that do not capture key aspects of the real-world reporting environment such as the presence of third-party information reporting. ${ }^{4}$

In this study, we first extend the standard economic model of tax evasion to incorporate the fact that the probability of detection varies with the type of income being under-reported (third-party reported versus self-reported income). Our model predicts that evasion will be low for third-party reported income items, but substantial for self-reported income items (as in the standard model). The theory also predicts that the effects of tax enforcement (audits, penalties) and tax policy (marginal tax rates) on evasion will be larger for self-reported income than for third-party reported income. Second, we provide a comprehensive empirical test of this model based on a large randomized field experiment carried out in collaboration with the Danish tax collection agency (SKAT) that overcomes the identification limitations of previous empirical work. The experiment imposes different audit regimes on randomly selected taxpayers, and has been designed to provide evidence on noncompliance as well as noncompliance responses to tax enforcement and tax rates under different information environments (third-party reporting versus self-reporting). Unlike previous studies - including the above-mentioned TCMP studies in the United States - our data allow us to distinguish precisely between income items subject to third-party reporting and income items subject to self-reporting for each individual in the sample, and to measure treatment effects on those two forms of income separately.

The experiment was implemented on a stratified random sample of about 42,800 individual taxpayers during the tax filing and auditing seasons of 2007 and 2008. In the first stage, taxpayers were randomly selected for unannounced tax audits of tax returns filed in 2007. These tax audits were comprehensive and any detected misreporting was corrected and penalized as appropriate according to Danish law. The selected taxpayers were not aware that the audits

\footnotetext{
${ }^{3}$ Even the TCMP does not provide exogenous variation in audit probabilities or tax rates.

${ }^{4}$ An important exception is Slemrod, Blumenthal, and Christian (2001) who analyze the effects of "threatof-audit" letters in a small field experiment in Minnesota.
} 
were part of a special study. For taxpayers not selected for these audits, tax returns were not examined under any circumstances. In the second stage, employees in both the audit and no-audit groups were randomly selected for pre-announced tax audits of tax returns filed in 2008. One group of taxpayers received a letter telling them that their return would certainly be audited, another group received a letter telling them that half of everyone in their group would be audited, while a third group received no letter. The second stage therefore provides exogenous variation in the probability of being audited. The empirical analysis is divided into three main parts.

The first part studies the anatomy of tax compliance based on the misreporting uncovered by tax inspectors in the first-stage audits. We find that the overall tax evasion uncovered by audits is modest: about $1.8 \%$ of total reported income. But there is considerable variation across income items depending on the information environment. For self-reported income, tax evasion as a share of income is about 37\%, whereas the tax evasion rate for third-party reported income is only about $0.3 \%$. Hence, the low evasion rate overall reflects that almost all of taxable income (95\%) is subject to third-party information reporting where the probability of detection is very high. It is important to keep in mind that these results capture only detectable evasion and are therefore lower bound estimates of true evasion. This is primarily relevant for self-reported income where traceability is relatively low, indicating that true evasion may be substantially more skewed towards self-reported income. The findings then suggest that overall tax evasion is low, not because taxpayers are unwilling to cheat, but because they are unable to cheat successfully due to the widespread use of third-party reporting. We also study the impact of non-economic factors such as gender, age, marital status, church membership, and place of residence that may serve as proxies for social and cultural factors. Consistent with earlier studies, we find that some of these variables are correlated with tax evasion. However, our empirical analysis shows that the impact of these social variables is very modest in comparison to variables that capture information and incentives to evade, namely the presence and size of self-reported income or losses.

The second part estimates the effect of the marginal tax rate on evasion using quasiexperimental variation in tax rates created by large and salient kinks in the nonlinear income tax schedule. The effect of marginal tax rates on evasion is theoretically ambiguous, and existing empirical results have been very sensitive to specification due to data and identification 
problems. As showed by Saez (2009) and pursued by Chetty et al. (2009) on Danish data, the compensated elasticity of reported income with respect to the marginal tax rate can be identified from bunching around kinks in progressive tax schedules. Comparing bunching evidence in pre-audit and post-audit income allows us to separately identify compensated elasticities of evasion versus legal avoidance. We find that evasion elasticities for self-employment income and stock-income are positive but small relative to the total elasticity. This implies that marginal tax rates have only modest effects on tax evasion that are dwarfed by the third-party reporting effects obtained in part one.

The third part studies the effect of tax enforcement on evasion. First, we consider the effect of audits on future reported income by comparing the full-audit and no-audit groups in the following year. Audits may affect future reported income by making taxpayers adjust their perceived probability of detection when engaging in tax evasion. Consistent with our theoretical model, we find that audits have a strong positive impact on reported income in the following year, with the effect driven almost entirely by self-reported income. This shows that audits have substantial positive effects on tax collection through behavioral responses to a higher perceived probability of detection. Second, we consider the effect of the probability of being audited on reported income by comparing the threat-of-audit letter and no-letter groups. Because taxpayers received the threat-of-audit letters shortly after receiving a pre-populated return containing third-party information, we focus on the effect of letters on self-reported adjustments to the pre-populated return. Consistent with the predictions of the standard economic model, we find that individuals receiving a threat-of-audit letter are more likely to adjust incomes on the pre-populated return in an upward direction, and that the effects are stronger for the $100 \%$ threat-of-audit letter than for the $50 \%$ letter.

The paper is organized as follows. Section 2 reviews the existing empirical literature. Section 3 presents a simple economic model of tax evasion with third-party reporting. Section 4 describes the Danish income tax context, experimental design, and data. Section 5 analyzes the anatomy of tax compliance. Section 6 estimates the effect of the marginal tax rate on evasion, while Section 7 estimates of the effect of tax enforcement (prior audits, audit threats) on evasion. Section 8 concludes. 


\section{Empirical Literature Review}

A large body of empirical work has studied the link between tax evasion and tax rates, penalties, audit probabilities, prior audit experiences, and socio-economic characteristics. Most of this literature relies on observational and non-experimental data, which creates measurement and identification problems. The measurement problem is that both the dependent variableevasion - and the independent variables - audits, threat of audits, penalties - are hardly ever observed accurately because taxpayers go to great lengths to conceal their evasion and because tax authorities do not make audit records or strategy publicly available except in aggregate form. The identification problem is that, even where reasonable measures of evasion and its various determinants have been available (mostly macro-data studies at the district or state level), the variation in tax rates and enforcement efforts is not exogenous but rather an endogenous response to compliance. This requires the use of instrumental variables. ${ }^{5}$ Andreoni, Erard, and Feinstein (1998) and Slemrod and Yitzhaki (2002) provide critical reviews of this literature and argue that none of the available instruments are likely to satisfy the required exogeneity assumptions. ${ }^{6}$

These generic problems motivate the use of an experimental approach to estimate evasion. Three sources of experimental data have been explored in the literature. The first source is the Taxpayer Compliance Measurement Program (TCMP) of the U.S. Internal Revenue Service. The household TCMP is a program of thorough tax audits conducted on a stratified random sample of personal income tax returns approximately every third year from 1963 to $1988 .{ }^{7}$ The TCMP studies have provided very useful information regarding the extent of evasion and the size of the tax gap, the difference between taxes owed and taxes paid voluntarily and on a timely basis. As pointed out by Andreoni, Erard, and Feinstein (1998), Bloomquist (2003), and Slemrod (2007), studies of TCMP data have shown that under-reporting is much higher for income categories with "little or no" third-party reporting (such as business income) than for income categories with "substantial" third-party reporting (such as wages and salaries). ${ }^{8}$

\footnotetext{
${ }^{5}$ Studies using district-level or state-level data on evasion and audit rates, and where an IV-strategy was adopted to control for the endogeneity of the audit rate, include Beron, Tauchen, and Witte (1992), Dubin, Graetz, and Wilde (1990), Dubin and Wilde (1988), and Pommerehne and Frey (1992).

${ }^{6}$ Recently, Feldman and Slemrod (2007) use charitable contributions to proxy for real incomes and evaluate indirectly tax evasion across income components.

${ }^{7}$ A less detailed version of the household TCMP, called the National Research Program (NRP), was implemented for the 2001 tax year.

${ }^{8}$ See also Klepper and Nagin (1989), Long and Swingden (1990), Christian (1994), and the Internal Revenue
} 
However, to our knowledge, no TCMP-based study has precisely and systematically compared compliance rates for third-party reported income items and self-reported income items as we do in this paper. ${ }^{9}$ Furthermore, TCMP does not provide useful exogenous variation in enforcement variables. Because audits are not pre-announced, there is no variation in the audit probability. Moreover, because audited taxpayers are told that they are participating in a special study and that audit selection is random, TCMP cannot be used to study the effects of audits on future reporting. The TCMP studies do not provide exogenous variation in the marginal tax rate to study the effects of the marginal tax rate on evasion.

A second source of experimental data has been generated by laboratory experiments. These are multi-period reporting games involving participants (mostly students) who receive and report income, pay taxes, and face risks of being audited and penalized. Lab experiments have consistently shown that penalties, audit probabilities, and prior audits increase compliance (e.g., Friedland, Maital, and Rutenberg, 1978; Becker, Buchner, and Sleeking, 1987; Alm, Jackson, and McKee, 1992a,b, 2008). But Alm, Jackson, and McKee (1992a,b) show that, when penalties and audit probabilities are set at realistic levels, their deterrent effect is quite small and the laboratory therefore tends to predict more evasion than we observe in practice. The key problem is that by its nature the lab environment is artificial, and therefore likely to miss important aspects of the real-world reporting environment. In particular, we are not aware of studies that incorporates third-party institutions into laboratory experiments.

The third source of data concerns a small but unique randomized field experiment involving about 1700 taxpayers in Minnesota studied by Slemrod, Blumenthal, and Christian (2001). Like part of the experiment we analyze in this paper, the Minnesota experiment sent threat-of-audit letters to taxpayers, thereby providing exogenous variation in the audit probability. As we do, they found that the treatment effects are heterogeneous with respect to income level and opportunities to evade. Surprisingly, they also found that a higher auditing probability lead to a reduction in reported income at the top of the distribution (although this effect was not statistically significant).

Service (1996, 2006).

${ }^{9}$ This is because TCMP studies are based solely on individual income tax data and do not use information returns. Most income lines on the individual tax return can include both third party reported and self-reported income. For example, wages and salaries include earnings reported on W2 information returns but also tips that are often never reported through information returns. 


\section{A Simple Economic Model of Tax Evasion}

We consider a version of the Allingham-Sandmo (henceforth AS) model with risk neutral taxpayers and an endogenous audit probability that depends on reported income. ${ }^{10}$ The basic model is similar to models that have been considered in the literature, but we will present the condition determining tax evasion in a slightly different manner in order to demonstrate that a high degree of tax compliance is potentially consistent with a low audit probability and a low, or even zero, penalty for evasion. We then introduce third-party information reporting into the model and discuss its implications for the structure of the (endogenous) audit probability and tax compliance behavior. Notice that the assumption of risk neutrality, besides simplifying the analysis, makes our case harder because risk-neutral taxpayers are more inclined to evade than risk-averse taxpayers.

We denote by $\bar{y}$ the true income and by $y$ the reported income of a representative taxpayer. The probability that the government detects undeclared income $\bar{y}-y$ through a tax audit is given by $p$. The probability of detection will typically be lower than the probability of audit, because tax audits may be unsuccessful in uncovering hidden income. ${ }^{11}$ We assume that the probability of detection is a decreasing function of reported income, $p=p(y)$ where $p^{\prime}(y)<0 .{ }^{12}$ The intuition for $p^{\prime}(y)<0$ is that, the more income the individual evades, the more likely is the tax administration to suspect under-reporting or to obtain evidence that evasion took place and hence carry out an audit. This fits well with the actual practices of professional tax preparers, who calibrate the audit probability to the wishes of their clients by deciding how aggressively to pursue a tax minimization strategy.

When evasion is detected, the taxpayer is forced to pay the evaded tax plus a penalty. The tax rate is proportional to income and given by $\tau$, and the penalty is proportional to the evaded tax and given by $\theta$. The risk-neutral taxpayer maximizes expected net-of-tax income, i.e.

$$
u=(1-p(y)) \cdot[\bar{y}-\tau y]+p(y) \cdot[\bar{y}(1-\tau)-\theta \tau(\bar{y}-y)]
$$

\footnotetext{
${ }^{10} \mathrm{~A}$ number of previous studies have considered an endogenous audit probability, including the original paper by Allingham and Sandmo (1972), Yitzhaki (1987), and the recent surveys by Slemrod and Yitzhaki (2002) and Sandmo (2005).

${ }^{11} \mathrm{As}$ in the original AS-model, we make the simplifying assumption that a tax audit either uncovers everything or nothing; there is no middle ground where tax evasion is partially uncovered.

${ }^{12}$ Allingham and Sandmo (1972) also considered the case where $p($.$) depends on reported income y$, whereas Yitzhaki (1987) considered a case where $p($.$) depends on undeclared income \bar{y}-y$. The results we show below hold under either formulation.
} 
An interior optimum for reported income $y$ satisfies the first-order condition $d u / d y=0$, which can be written as

$$
\left[p(y)-p^{\prime}(y)(\bar{y}-y)\right](1+\theta)=1
$$

The second-order condition to this problem puts a restriction on the second-order derivative of $p(y) .{ }^{13}$ If we denote undeclared income by $e$ so that reported income is given by $y=\bar{y}-e$, we may define the elasticity of the detection probability with respect to undeclared income as $\varepsilon \equiv \frac{d p}{d e} \frac{e}{p}=-p^{\prime}(y) \frac{\bar{y}-y}{p} \geq 0 .{ }^{14}$ The first-order condition determining reported income can then be written as

$$
p(y) \cdot(1+\theta) \cdot(1+\varepsilon(y))=1
$$

The right-hand side of the first-order condition is the marginal benefit of an extra dollar of tax evasion, while the left-hand side is the expected marginal cost of an extra dollar of tax evasion. Under $\varepsilon=0$ as in the simplest model of evasion where $p$ is independent of $y$, the expected marginal cost equals the probability of detection $p$ times the evaded tax plus penalty, $1+\theta$. The presence of the elasticity $\varepsilon$ in the formula reflects that the taxpayer by evading one more dollar incurs a higher probability of detection on all the infra-marginal units of tax evasion. Interestingly, this simple model is consistent with less than full tax evasion even in the case of a zero penalty, i.e. $\theta=0$. In this case, partial evasion may be better than full evasion because it involves a lower probability of being detected and having to pay the full statutory tax (but no penalty).

The comparative statics of this type of model have been analyzed in the literature (see e.g., Yitzhaki, 1987). A higher penalty and a positive shift of the detection probability are both associated with lower tax evasion. Moreover, as can be seen directly from (3), the marginal tax rate has no impact on tax evasion. This result relies on the assumptions of risk-neutrality, linear taxation, and a linear penalty in evaded tax. In particular, the combination of a linear penalty and linear taxation implies that the substitution effect of the marginal tax rate is zero, while risk-neutrality implies that the income effect is also zero. Under a nonlinear penalty, the marginal tax rate will have a nonzero substitution effect with the sign of the effect depending on the second-order derivative of the fine. Moreover, in a nonlinear tax system, an increase in

\footnotetext{
${ }^{13}$ The second-order condition is given by $2 p^{\prime}(y)-p^{\prime \prime}(y)(\bar{y}-y)<0$. A sufficient condition for this to hold is that $p($.$) is convex so that p^{\prime \prime}(y)>0$.

${ }^{14}$ We could alternatively define the elasticity with respect to reported income $y$, but it simplifies the expression slightly to define the elasticity with respect to undeclared income $e \equiv \bar{y}-y$.
} 
the marginal tax rate for a constant total tax liability can have a positive substitution effect on evasion, although this is true only under an endogenous audit probability and the result depends on the second-order derivative of the audit probability. In general, the substitution effect of the marginal tax rate on evasion is theoretically ambiguous and its sign is an open empirical question. Below we estimate the compensated evasion elasticity using evidence on bunching around kink points in a nonlinear tax schedule.

The strongest critique of the economic model of tax evasion centers on its predictions of the level of non-compliance. Condition (3) implies that the taxpayer should increase evasion as long as

$$
p(y)<\frac{1}{1+\theta} \cdot \frac{1}{1+\varepsilon(y)} .
$$

The fact that the observed $p$ and $\theta$ are very low is often argued to imply that it is privately optimal for taxpayers to increase evasion and that they are therefore complying too much from the perspective of the standard economic model. This reasoning ignores the important role of $\varepsilon(y)$, and this is particularly important in a tax system using third-party information reporting. As we will argue, the presence of third party reporting puts specific structure on the functions $p(y)$ and $\varepsilon(y)$.

Third-party reporting can be embedded in the model in the following way. Let true income be given by $\bar{y}=\bar{y}_{t}+\bar{y}_{s}$, where $\bar{y}_{t}$ is subject to third-party reporting (wages and salaries, interest income, mortgage payments, etc.) and $\bar{y}_{s}$ is self-reported (self-employment income, various deductions, etc.). For third-party reported income, assuming there is no collusion between the taxpayer and the third party, the probability of detection will be close to 1 as systematic matching of tax returns and information reports will uncover any evasion. ${ }^{15}$ By contrast, the detection probability for self-reported income is very low because there is no smoking gun for tax evasion and tax administrations have very limited resources to carry out blind audits.

Based on these observations, it is natural to assume that the probability of detection $p(y)$ is very high for $y<\bar{y}_{t}$, very low for $y>\bar{y}_{t}$, and decreases rapidly around $y=\bar{y}_{t}$. Notice that these properties rely on a specific sequence of income declaration for the taxpayer: as reported income $y$ is increased from 0 to $\bar{y}$, the taxpayer first declares income with a high detection probability

\footnotetext{
${ }^{15}$ Kleven, Kreiner, and Saez (2009) study the issue of collusion and third-party reporting in detail, and demonstrate that collusion cannot be sustained in large firms using verifiable business records even with low audit rates and penalties. However, collusion may be sustainable for sufficiently small firms and for firms off the books.
} 
and then declares income with a low detection probability. Given that the tax rate and penalty are the same across different income items, this is the optimal sequence for the taxpayer. These remarks imply that the detection probability has a shape like the one shown in Figure 1, where $p(y)$ is initially very close to 1 and then decreases rapidly towards zero around the threshold $\bar{y}_{t} \cdot{ }^{16}$

In this model, the taxpayer's optimum will be at a point to the right of $\bar{y}_{t}$ as shown in the figure. At this equilibrium, the detection probability $p(y)$ is much lower than $\frac{1}{1+\theta}$, but the elasticity $\varepsilon(y)$ is very high as evasion is close to the level where third-party reporting binds. For modern tax systems based on extensive use of information reporting $\left(\bar{y}_{s} / \bar{y}\right.$ is low), this model predicts a low overall evasion rate $\left((\bar{y}-y) / \bar{y} \leq \bar{y}_{s} / \bar{y}\right.$ is low $)$, a high evasion rate for self-reported income $\left((\bar{y}-y) / \bar{y}_{s}\right.$ is high), and a low detection probability $p(y)$ at the equilibrium. The model also predicts that the deterrence effect of increased enforcement is small overall, but significant for self-reported income. We show below that this simple model is consistent with the empirical findings we obtain from the randomized tax audit experiment.

\section{Context, Experimental Design, and Data}

\subsection{The Danish Income Tax and Enforcement System}

The Danish tax system is described in Table 1. Panel A described the various tax bases and Panel B describes the tax rate structure. Instead of applying a progressive rate structure to a single measure of taxable income, the Danish tax system is based on a number of different income concepts that are taxed differently. Labor income first faces a flat rate payroll tax of $8 \%$ that is always deducted when computing the other taxes, implying that the effective income tax rate is only $92 \%$ of the statutory rate.

Both national and local income taxes are enforced and administered in an integrated system. The national income tax is a progressive three-bracket system imposed on a tax base equal to personal income (labor income, transfers, pensions, and other adjustments) plus capital income

\footnotetext{
${ }^{16} \mathrm{~A}$ microfoundation of the $p$-shape in the figure would allow for many income items, some of which are thirdparty reported and some of which are self-reported. In general, let there be $N$ third-party reported items with true incomes $\bar{y}_{t}^{1}, \ldots, \bar{y}_{t}^{N}$, and let there be $M$ self-reported items with true incomes $\bar{y}_{s}^{1}, \ldots, \bar{y}_{s}^{M}$. The $N$ third-party reported items have higher detection probabilities than the $M$ self-reported items, but there is heterogeneity in the probability across items in each group. As argued above, an optimizing taxpayer choosing total reported income $y$ will include income items sequentially such that the detection probability is decreasing in declared income. In this case, it is natural to assume that the detection probability has a shape like the one showed in Figure 1.
} 
if capital income is positive with marginal tax rates equal to $5.5 \%, 11.5 \%$, and $26.5 \%$. The regional income tax is based on taxable income (personal income plus net capital income minus deductions) above a standard exemption at a flat rate that varies by municipality and is equal to $32.6 \%$ on average. Finally, at the national level, stock income (dividends plus realized capital gains from sales of corporate stock) is taxed separately by a progressive two-bracket system with rates equal to $28 \%$ and $43 \%$.

About $88 \%$ of the Danish population is liable to pay income tax, and all tax liable individuals are required to file a return. ${ }^{17}$ Income tax filing occurs in the Spring of year $t+1$ for income earned in year $t$. By the end of January in year $t+1$, SKAT will have received most information reports from third parties. Notice that such information reporting includes, but is not limited to, income where taxes have been withheld at source during year $t$. Based on the third-party reports, SKAT constructs pre-populated tax returns that are sent to taxpayers in mid-March. Other than third-party information, the pre-populated return may contain additional 'hard' information that SKAT possesses such as an estimated commuting allowance based on knowledge of the taxpayer's residence and work address. Upon receiving the pre-populated return, the taxpayer has the option of making adjustments and submit a final return before May $1 .{ }^{18}$ This filing system implies that, for most tax filers, the difference between income items on the final return and the pre-populated return is a measure of item-by-item self-reported income. However, there are some exceptions where the pre-populated return contains certain elements of self-reporting or where third-party reporting arrives too late to be included on the pre-populated return.

After each tax return has been filed, a computer-based system generates audit flags based on the characteristics of the return. Audit flags do not involve any randomness element and are a deterministic function of the computerized tax information available to SKAT. Flagged returns are looked at by a tax examiner, who decides whether or not to instigate an audit based on the severity of flags, local knowledge, and resources. The audit rate for the entire population of individual tax filers is $4.2 \% .^{19}$ Audits may generate adjustments to the final return and

\footnotetext{
${ }^{17}$ The group of citizens who are not tax liable and therefore not required to file a return consists mostly of children under the age of 16 who have not received any taxable income over the year.

${ }^{18}$ New returns can be submitted by phone, internet, or mail, and the taxpayer may keep filing new returns all the way up to the deadline, only the last return counts. If no adjustments are made, the pre-populated return counts as the final return.

${ }^{19}$ These audits vary with respect to their breadth and depth, and the audit rate may therefore overstate the intensity of auditing. This is important to keep in mind when comparing the Danish audit rate to audit rates in other countries such as the United States where the audit rate is lower.
} 
a tax correction. In the case of underreporting, the taxpayer has the option of paying taxes owed immediately or postponing the payment at an interest. If the underreporting is viewed by the tax examiner as attempted fraud, a fine may be imposed. In practice, such fines a rare because it is difficult to draw the line between honest mistakes and deliberate fraud. Repeated underreporting for the same item increases the penalty applied. An audit may alternatively find over-reporting, in which case excess taxes are repaid with interest.

\subsection{Experimental Design}

The experiment we analyze was implemented by SKAT on a stratified random sample of 25,020 employees and 17,764 self-employed. ${ }^{20}$ The sample of employees was stratified according to tax return complexity, with a higher sampling rate for employees with high-complexity returns ('heavy' employees) and lower sampling rate for employees with low-complexity returns ('light' employees). ${ }^{21}$ The experimental treatments and their timing are shown in Figure 2.

The experiment was implemented in two stages during the filing and auditing seasons of 2007 and 2008. In the first stage, taxpayers were randomly assigned to a 100\% audit group and a $0 \%$ audit group. All taxpayers in the 100\% audit group were subjected to unannounced tax audits of tax returns filed in 2007 (for 2006 income), meaning that taxpayers were unaware at the time of filing that they had been selected for an audit. These tax audits were comprehensive in the sense that every item on the return was examined, and the audits used up $21 \%$ of all resources devoted to tax audits in 2007. ${ }^{22}$ Audited taxpayers were not told that the audits were part of a special study. In the case of detected misreporting, the tax liability was corrected and a penalty possibly imposed depending on the nature of the error and as appropriate according to Danish law. Taxpayers in the $0 \%$ audit group were never audited even if the characteristics of the return would normally have triggered an audit. ${ }^{23}$

Although SKAT intended to audit all taxpayers in the $100 \%$ audit group, the actual audit

\footnotetext{
${ }^{20}$ The 'employee' category include transfer recipients such as retired and unemployed individuals, and would therefore be more accurately described as 'not self-employed'.

${ }^{21}$ Besides the stratifications with respect to employment status (employee/self-employed) and tax return complexity (light employee/heavy employee), an additional stratification was made with respect to geographical location. The geographical stratification ensured that the same number of taxpayers was selected from each of the 30 regional tax collection centers in Denmark.

${ }^{22}$ SKAT made considerable effort to ensure a uniform and thorough auditing procedure across all taxpayers in the full-audit group. This included organizing training workshops for the tax examiners involved in the experiment, and providing detailed auditing manuals to each examiner.

${ }^{23}$ However, SKAT did maintain the option of carrying out retrospective audits after the completion of the experiment.
} 
rate was in fact a bit lower than $100 \%$. This is because some tax returns were impossible to audit due to special circumstances such as individuals dying, leaving the country, or being unreachable for some other reason. In the empirical analysis below, estimates are always based on the entire $100 \%$ audit group (including those who could not be audited), so that we are measuring intent-to-treat effects rather than treatment effects. As the actual audit rates were $98.7 \%$ for employees and $92 \%$ for self-employed individuals, our estimates are very close to actual treatment effects. ${ }^{24}$

Moreover, despite the large amount of resources spent on the experimental audits, they are unlikely to uncover all tax evasion for all taxpayers, and our results therefore provide lower bounds on total individual income tax evasion. The same issue arises in the TCMP studies in the United States, which blow up tax evasion uncovered by audits (and without the help of third-party information returns) by a multiplier factor of 3.28 to arrive at the official tax evasion estimates. Unfortunately, this blowing-up factor is large and has a very large measurement error, so that total tax evasion rates are at best rough approximations. ${ }^{25}$ In this study, we therefore focus solely on detectable tax evasion.

In the second stage, individuals in both the $100 \%$ audit and $0 \%$ audit groups were randomly selected for pre-announced tax audits of tax returns filed in 2008 (for 2007 income). This part of the experiment was implemented only for the employees since it was administratively infeasible for SKAT to include the self-employed. The pre-announcements were made by official letters from SKAT sent to taxpayers one month prior to the filing deadline on May $1,2008 .{ }^{26}$ A third of the employees in each group received a letter telling them that their return would certainly be audited, another third received a letter telling them that half of everyone in their group would be audited, and the final third received no letter. The second stage therefore provides exogenous variation in the probability of being audited, conditional on having been audited in

\footnotetext{
${ }^{24}$ We prefer to present intent-to-treat effects rather than treatment effects (which would be obtained by running a 2SLS regression on actual audit and using treatment group as an instrument), because the impossibility to audit some returns reflects actual limitations in the real-world auditing environment.

${ }^{25}$ The 3.28 factor was based on a survey of taxpayers from the TCMP survey in 1976. Obviously, such selfreported levels of undetected tax evasion are likely to be very noisy. In addition to this blowing up factor, the Internal Revenue Service has developed special surveys designed to measure specifically under-reported tip income and informal supplier income. See Internal Revenue Service, 1996, pp. 20-21 and pp. 41-43 for complete details.

${ }^{26}$ The pre-populated returns are administered around mid-March after which taxpayers are allowed to file their tax return. When the pre-announcement letters were delivered, some taxpayers (around 17\%) had already filed a new return. However, as explained in the previous section, taxpayers are allowed to change their returns all the way up to the deadline. Only the final report is considered by tax examiners. The letters emphasized this possibility of changing the report.
} 
the first stage or not. The audit probability is $100 \%$ for the first group, $50 \%$ for the second group, and equal to the current perceived probability in the third group.

The wording of the threat-of-audit letters was designed to make the message simple and salient. The wording of the $100 \%$ (50\%, respectively) letter was the following: "As part of the effort to ensure a more effective and fair tax collection, SKAT has selected a group of taxpayers - including you - for a special investigation. For (half the) taxpayers in this group, the upcoming tax return for 2007 will be subject to a special tax audit after May 1, 2008. Hence, (there is a probability of 50\% that) your return for 2007 will be closely investigated. If errors or omissions are found, you will be contacted by SKAT." Both types of letter included an additional paragraph saying that "As always, you have the possibility of changing or adding items on your return until May 1, 2008. This possibility applies even if you have already made adjustments to your return at this point."

After returns had been filed in 2008, SKAT audited all taxpayers in the 100\%-letter group and half of all taxpayers (selected randomly) in the 50\%-letter group. However, to save on resources, these audits were much less rigorous than the first round of audits in 2007. Hence, we do not show results from the actual audits in 2008, but focus instead on the variation in audit probabilities created by the threat-of-audit letters.

\subsection{Data}

The data is obtained from SKAT's Business Object Database, which contains all information available to SKAT concerning each taxpayer. This includes all income items from the thirdparty information reports and from the pre-populated, filed, and audited tax returns for each

year and each taxpayer. For the 2007 filing season (2006 income), we extract item-by-item income data from the third-party information report $(\mathbf{I})$, the pre-populated return $(\mathbf{P})$, the filed return $(\mathbf{F})$, and the after-audit return $(\mathbf{A})$. For the 2008 filing season (2007 income), we extract income data from the third-party information report $(\mathbf{I})$, the pre-populated return $(\mathbf{P})$ and the filed return $(\mathbf{F})$.We also extract variables from the computer-generated audit flag system (presence and number of flags) on which audit decisions would normally be based. Finally, the database contains a limited number of socio-economic variables such as age, gender, residence, and marital status. For employees, we also extracted information on the industrial sector of the employer (22 categories) and the total number of employees at the firm. 


\section{The Anatomy of Tax Compliance}

\subsection{Overall Compliance}

This section analyzes data from the baseline audits of tax returns filed in 2007 for incomes earned in 2006 in the 100\% audit group. Table 2 presents various audit adjustments statistics for total income defined as the sum of third-party and self-reported incomes in Panel A, and for thirdparty and self-reported income separately in Panel B. Starting with total net income and total tax at the top of the tables, those statistics are then presented by specific income components in lower rows. For each row, Panel A shows the percent of tax filers with non-zero income (column (1)), average reported income before audit (column (2)), the total audit adjustment (column (3)), the audit adjustment due to under-reporting (column (4)), and the audit adjustment due to over-reporting (column (5)). All amounts are reported in Danish Kroner and standard errors are shown in parentheses. The statistics have been calculated using population weights to reflect averages in the full population of tax filers in Denmark.

Total net income is equal to 206,000 kroner on average (around $\$ 40,000$ ), and the total tax liability before audit adjustments is equal to about 70,000, corresponding to an average tax rate of $34 \%$. The single most important component of income is personal income, which includes earnings, transfers, pensions, and other adjustments (see Table 1 for a detailed definition). ${ }^{27}$ Personal income is reported by $95.2 \%$ of tax filers and the average amount is close to total net income as the other components about cancel out on average. Capital income is negative on average mainly due to mortgage interest payments and is also very common. Capital income is equal to about $-5 \%$ of total net income and about $94 \%$ of tax filers report non-zero capital income. Deductions also represent about $-5 \%$ of net income, but only $60 \%$ of tax filers report deductions. Stock income constitutes less than $3 \%$ of net income and is reported by about $22 \%$ of tax filers. Self-employment income is about $5 \%$ of net income and is reported by $7.6 \%$ of tax filers.

Note that each of the components of net income are themselves the sum of single line items (which correspond to specific boxes on the tax return). A given line item is either always positive (such as interest income received) or always negative (such as mortgage interest payments). As we shall see, for third party reported items, the distinction between positive line items

\footnotetext{
${ }^{27}$ In all tables, the personal income variable includes only earnings by employees, while earnings by the selfemployed are reported separately as part of self-employment income.
} 
and negative line items is critical. Therefore, we split net income into "positive income" and "negative income" defined as the sum totals of all the positive and negative income components, respectively.

Column (3) shows that the adjustment amounts are positive for all categories, implying that taxpayers do indeed evade taxes. ${ }^{28}$ These adjustments are strongly statistically significant in all cases, except for capital income where detected tax evasion is very small. Total detectable tax evasion can be measured by the adjustment of net income and is equal to 3,744 kroner (about $\$ 750$ ), corresponding to about $1.8 \%$ of net income. The tax lost through detectable tax evasion is 1,670 kroner, or $2.4 \%$ of total tax liability. ${ }^{29}$ Considering the positive and negative income items separately, the evasion rate is $1.4 \%$ for positive income and $0.8 \%$ for negative income (in absolute value). Hence, overall tax evasion appears to be very small in Denmark despite the high marginal tax rates described in the previous section. However, the low evasion rates reported above masks substantial heterogeneity across different income components, with evasion rates equal to $1.1 \%$ for personal income, $1.4 \%$ for capital income (in absolute value), $1.4 \%$ for deductions (in absolute value), $4.9 \%$ for stock income, and $8.1 \%$ for self-employment income. We come back to the reasons for this heterogeneity below.

The audit adjustments discussed so far reflect a combination of upward adjustments (underreporting) and downward adjustments (over-reporting), which are reported separately in columns (4) and (5). We see that under-reporting takes place in all income categories, and that the detected under-reporting is always strongly significant. The heterogeneity across income categories follows the same pattern as for the total adjustment. The amounts of over-reporting are always small but statistically significant in most income categories. The small amount of over-reporting most likely reflects honest mistakes resulting from a complex tax code and the associated transaction costs with filing a tax return correctly. ${ }^{30}$

\footnotetext{
${ }^{28}$ For negative items (such as mortgage interest payments included in capital income for example), a positive adjustment means that the absolute value of the mortgage interest payment was reduced. We use this convention so that upward adjustments always mean higher net income (and hence higher net tax liability).

${ }^{29}$ Estimated under-reporting from the TCMP study for the US individual income tax for 1992 is $13.2 \%$ of total tax liability (Internal Revenue Service, 1996, Table 6, row 3, p .13). However, as discussed above, this factor includes a multiplier factor of 3.28 of detected under-reporting so that actual under-reported income in the US should be around 4\%, higher than in Denmark but not overwhelmingly so.

${ }^{30}$ Notice that the Danish system of pre-populated tax returns described in Section 4 implies that tax return filing is not in itself associated with transaction costs (because the taxpayer can always choose to do nothing, in which case the pre-populated return is automatically filed). Transaction costs are incurred only by investing the time and/or money to ensure a correct filing.
} 


\subsection{Self-Reported vs. Third-Party Reported Income}

Each income category in Table 2 consists of some income items that are self-reported and other income items that are subject to third-party reporting. But the prevalence of information reporting varies substantially across income categories, with substantial third-party reporting for earnings and personal income at one end of the spectrum and very little third-party reporting for self-employment income at the other end of the spectrum. The results described above therefore suggest that evasion rates are higher when there is little third-party reporting, consistent with the findings of the TCMP studies in the United States discussed in Section 2. A key advantage of our data is that it allows an exact breakdown of income into third-party reported income and self-reported income, facilitating a more rigorous analysis of the role of third-party reporting for tax compliance. We present such an analysis in Panel B of Table 2 which displays the amount of third-party reported income (column (6)), the amount of third-party under-reporting (column (7)), the amount of self-reported income (column (8)), and the amount of self-reported underreporting (column (9)).

Columns (6) and (8) show that the use of third-party reporting is very pervasive in Denmark. For total net income, third-party reporting constitutes about $95 \%$ of income while self-reporting is responsible for only 5\%. The share of third-party reporting in total positive income is $92 \%$ and its share in total negative income is $74 \%$. While the widespread use of third-party reporting indicate that detection probabilities are very high on average, there is considerable heterogeneity across income components. For personal income, third-party reporting constitutes more than $100 \%$ of total income as self-reported income includes certain negative adjustments and is negative on average. Capital income reported by third-parties is negative on net due to interest payments on mortgages, bank loans, etc., and is more than $100 \%$ of total negative capital income as self-reported capital income is positive (but relatively small). For the remaining income components, the share of third-party reporting is $62.3 \%$ for deductions, $67.1 \%$ for stock income, and only $11.2 \%$ for self-employment income. It is interesting to note that third-party reporting is not strictly zero even for self-employed individuals. An example of third-party reporting for self-employed individuals would be an independent contractor working for a firm (but not as a formal employee), which reports the contractor compensation directly to the government. The fact that self-employment income consists of both self-reported income and third-party reported income is useful, because it will allow us to explore the separate implications of third-party in- 
formation versus being self-employed.

We split total tax evasion into under-reporting of self-reported income and under-reporting of third-party reported income. As mentioned above, we observe line-by-line income amounts in the information report $(\mathbf{I})$, the filed tax return $(\mathbf{F})$, and the audit-adjusted report (A). Each report consists of line items that are either always positive (as in the case of earnings) or always negative (as in the case of deductions and losses). Consider first the always-positive line items (such as regular wage earnings for example). We can say that under-reporting of third-party income took place if the individual reported less on her return than what is obtained from third-party reports and there was a subsequent upward audit adjustment. Formally, if we have $\mathbf{F}<\mathbf{A}<\mathbf{I}$, then third-party cheating is equal to $\mathbf{A}-\mathbf{F}$. If we have $\mathbf{F}<\mathbf{I} \leq \mathbf{A}$, then third-party cheating is equal to $\mathbf{I}-\mathbf{F}$. In all other cases (i.e., if either $\mathbf{A} \leq \mathbf{F}<\mathbf{I}$ or $\mathbf{F} \geq \mathbf{I}$ ), third-party cheating is zero. Given this procedure, we measure under-reporting of self-reported income as the residual difference between total under-reporting and third-party under-reporting.

Consider next the always-negative line items such as losses and deductions. If the taxpayer reports larger losses and deductions (in absolute value) than what is obtained from third-party reports and then receives an upward audit adjustment (i.e., is denied part or all of those extra losses), this may reflect self-reported under-reporting (that is later denied in the audit) or trying to misreport third-party reported losses or deductions. Our data do not allow us to separate between the two. It is possible to estimate an upper bound for third-party cheating by saying that, if $\mathbf{F}<\mathbf{I}=\mathbf{A}$, then we can call $\mathbf{I}-\mathbf{F}$ third-party cheating. However, this upper bound is likely to capture mostly self-reported cheating and is therefore not very useful. Therefore, we will define third-party under-reporting only for positive income items. ${ }^{31}$

We find a very strong variation in tax evasion depending on the information environment. For third-party reported income, the evasion rate is always very small: it is equal to $0.2 \%$ for total positive income and between $0.2 \%$ and $0.9 \%$ across all the different categories. Interestingly, the evasion rate for self-employment income conditional on third-party reporting is only $0.9 \%$, suggesting that tax evasion among the self-employed is large because of the information environment and not because of other aspects of being self-employed (such as the absence of

\footnotetext{
${ }^{31}$ For negative items, we can say with confidence that a reporting error in the third party category took place only if reported deductions/losses are smaller (in absolute value) than third-party reported deductions/losses and there is a subsequent audit adjustment. However, such mis-reporting is by definition unfavorable to the taxpayer and leads to a downward audit adjustment. Such events are extremely rare.
} 
withholding or preferences). By contrast, tax evasion for self-reported income is substantial: the evasion rate for total positive income is $15.8 \%$. For the different subcomponents, the evasion rates are equal $8.7 \%$ for capital income, $14.9 \%$ for stock income, and $11.6 \%$ for self-employment income. Notice that the evasion rate for self-employment income is not particularly high compared to the other forms of income once we condition on self-reporting. For total self-reported net income, the tax evasion rate is equal to $36.9 \%$. Because self-reported net income consists of positive amounts and negative amounts that just about cancel on average (self-reported net income is quite small), measuring tax evasion as a share of self-reported net income may give an exaggerated representation of the evasion rate. On the other hand, and as discussed earlier, these estimates capture only detectable evasion and are therefore lower bounds on true evasion. This is especially important for self-reported income where there is very little traceable evidence that can provide a smoking gun for evasion, implying that true evasion rates are likely to be even more skewed towards self-reported income.

The strong association between tax evasion and third-party information is strongly suggestive that information reporting is crucial for compliance, although we should obviously be cautious in making causal statements in the absence of exogenous variation in information reporting. ${ }^{32}$ Another potential caveat in interpreting the results is that, since third-party reporting often goes hand in hand with income tax withholding, it is not a priori clear whether the variation in tax evasion is driven mostly by one or the other. ${ }^{33}$ As mentioned above, the fact that the evasion rate for self-employment income (which is never withheld at source) is very low in the presence of third-party information suggests that information reporting is more important than withholding. To explore this point further, Table 3 breaks down third-party reported income into items that are also subject to withholding (mainly earnings, pensions, and transfers) and items that are not (such as third-party reported self-employment income and stock income). The table shows that, once there is information reporting, evasion rates are always very small whether or not there is also withholding. The evasion rate is $0.2 \%$ in the presence of withholding and $2.1 \%$ in the absence of withholding. While these results cannot rule out an independent

\footnotetext{
${ }^{32}$ Variation in information reporting across different income items may be correlated with unobserved factors (such as heterogeneous preferences across individuals with different forms of income) that have an impact on tax evasion on their own. While we cannot rule out such effects, it appears implausible that the strong association between evasion and information is entirely non-causal.

${ }^{33}$ The U.S. TCMP studies note that income items subject to both withholding and third-party reporting have lower evasion rates than income items subject solely to third-party reporting (IRS, 1996, 2006).
} 
effect of withholding on compliance, they do suggest that third-party reporting is the more crucial element in effective enforcement.

To summarize these results, tax evasion is very low overall and equal to about $1.8 \%$ of total income. The low evasion rate overall reflects that almost all of taxable income (95\%) is subject to third-party information reporting where the probability of detection is very high and tax evasion is essentially zero. Once we zoom in on purely self-reported income, tax evasion rates are substantial. Although self-reported income constitutes only about $5 \%$ of total income, it is responsible for $87 \%$ of detected tax evasion. These results suggest that overall tax evasion is low, not because taxpayers are unwilling to cheat, but because they are unable to cheat successfully due to the widespread use of third-party reporting.

\subsection{Social versus Information Factors}

To explore the role of social, economic, and informational factors in determining noncompliance, Table 4 reports the results of OLS regressions of an audit adjustment dummy on a number of dummy covariates. The regressions are run for the full-audit group using population weights, and consider adjustments in total net income as the dependent variable. Panel A (columns (1)-(4)) shows results for a basic set of explanatory variables, while Panel B (columns (5)-(8)) considers a richer set of explanatory variables. Column (1) considers five social variables: gender, marital status, church membership, geographical location (dummy for living in the capital Copenhagen), and age (dummy for being older than 45 years of age). The table shows that being female and a church member are both negatively associated with noncompliance, while being married is positively associated with noncompliance. The effects of location and age are small and insignificant. Column (2) adds three socio-economic variables: home ownership, firm size (a dummy for working in a firm with less than 10 employees), and industrial sector (a dummy for working in the "informal" sector defined as agriculture, forestry, fishing, construction, and real estate). ${ }^{34}$ Being a home owner, working in a small firm, and working in the informal sector are all positively associated with noncompliance.

Column (3) considers information-related tax return factors, in particular the presence and size of self-reported income: a dummy for having non-zero self-reported income, a dummy for having self-reported income above 20,000 kroner, and a dummy for having self-reported income

\footnotetext{
${ }^{34}$ The informal sector classification is meant to capture industries that are generally prone to informal activities.
} 
below -10,000 kroner. We also include a dummy for having been flagged by the computerbased audit selection system (described in Section 4), because audit flags are to a large extent a (complex) function of self-reported income. The results show very strong effects of all these information-related tax return variables. Column (4) brings all the variables together in order to study their relative importance. The results show that by far the strongest predictors of evasion are the variables capturing self-reported income. The effect of firm size is also fairly strong and significant, while the effect of "informal" industrial sector becomes insignificant. As for the social variables, the negative effects of female gender and church membership are now smaller although they remain significant, while the strong positive effect of home ownership disappears. There is a small but significant effect of marital status, whereas location and age are insignificant.

It is illuminating to consider the R-squares and adjusted R-squares across the different specifications. The specification including only self-reported income variables explains about $17.1 \%$ of the variation, while the specification with only socio-economic factors explains just about $2.1 \%$. Adding socio-economic variables to the specification with tax return variables have almost no effect on the R-square. This provides suggestive evidence that information, and specifically the presence and size of income that is difficult to trace, is the most central aspect of the compliance decision.

In columns (5)-(8), we investigate whether these findings are robust to including a much richer set of explanatory variables. Besides the basic variables described above, we include 6 location dummies (corresponding to the 6 main geographical areas of Denmark), 4 age group dummies, 5 firm size dummies, 22 industry sector dummies, 6 income group dummies, dummies for having non-zero self-employment income, capital income, stock income, and deductions, and finally a dummy for having experienced an audit adjustment in the two years prior to the experiment. The overall conclusions are the same as above. Although several of the socioeconomic variables are significant, the largest effects by far are driven by tax variables capturing information: the presence and size of self-reported income and self-employment income, the audit flag dummy, and prior audit adjustments. As before, the R-squares show that social variables explain a very small part of the variation, while tax return variables explain a much larger part of the variation. This confirms the conclusion from above that information and traceability are central to the compliance decision. 
In sum, these descriptive findings confirm the general conclusion from Table 2 that selfreported vs. third-party reported income is the critical distinction for tax evasion. It should be noted however that several social variables continue to have a significant impact on evasion, although relatively small in magnitude, even after controlling for tax-related information variables.

\section{The Effect of the Marginal Tax Rate on Evasion}

The effect of marginal tax rates on tax evasion is a central parameter for tax policy design. As discussed earlier, the effect of the marginal tax rate on tax evasion is theoretically ambiguous, not just because of income effects, but because the substitution effect can be either positive or negative depending on the structure of penalties, taxes, and detection probabilities. In this section, we try to sign the substitution effect by presenting evidence on the compensated elasticity of tax evasion with respect to the marginal tax rate.

An early study of this important parameter is provided by Clotfelter (1983), who estimates the responsiveness of evasion to the marginal tax rate and income using cross-sectional variation from the 1969 TCMP in the United States. He finds large positive effects of both tax rates and income on evasion. An issue with this approach is that the cross-sectional variation in individual marginal tax rates is driven mostly by income, so that there is very little independent variation in the two variables of interest. To deal with this issue, Feinstein (1991) considers pooled data from the 1982 and 1985 TCMPs, thereby allowing for independent variation in the two variables created by changes in tax rates over time for a given level of income. In sharp contrast to Clotfelter's results, Feinstein finds a substantial negative effect of the marginal tax rate on evasion. A broad concern with these approaches is that the observed tax rate variation is likely to be endogenous due to both unobserved heterogeneity and simultaneity in the determination of tax rates and evasion. We therefore follow a different approach using the quasi-experimental variation created by the discontinuity in marginal tax rates around kinks in the tax schedule.

The Danish tax system described in Section 4.1 consists of two separate piecewise linear schedules: a three-bracket income tax and a two-bracket stock income tax. The most significant kinks are created by the top bracket threshold in the income tax (where the marginal tax increases from $49 \%$ to $62 \%$ ) and the bracket threshold in the stock income tax (where the marginal tax increase from $28 \%$ to $43 \%$ ). Economic theory predicts that taxpayers will respond 
to such jumps in marginal tax rates by bunching at the kink points. Saez (2009) shows that the amount of bunching is proportional to the compensated elasticity of reported income with respect to the net-of-tax rate since the identifying variation is driven by a discontinuous jump in the marginal tax rate with no change in the (continuous) tax burden around the kink. Saez (2009) develops a simple method to estimate the elasticity using bunching evidence. This method has been recently pursued on Danish data by Chetty et al. (2009), who find evidence of substantial bunching around the top kink in the income tax system. We also consider the top kink in the income tax, focusing on individuals with self-employment income where evasion is substantial and a significant evasion response is a priori likely. Moreover, we consider the kink in the stock income tax, since this kink is also large and much of stock income is self-reported and therefore prone to evasion. Our key contribution to the existing bunching literature and to the tax responsiveness literature more generally is that the combination of pre-audit and post-audit data allows us to break down total behavioral responses into evasion responses and legal avoidance responses. ${ }^{35}$

To evaluate the importance of bunching, Figure 3 plots empirical distributions of taxable income (excluding stock-income) in Panel A and stock income in Panel B around the major cutoffs in the income tax and stock income tax schedules described above. Panel A shows the empirical distributions of pre-audit taxable income (black curve) and post-audit taxable income (grey curve) for the self-employed in 2006 around the top kink at 318,700 kroner (vertical line). The figure has been constructed by grouping individuals into 3000 kroner bins and plotting the number of taxpayers in each bin. Consistent with Chetty et al. (2009), we see very strong bunching in filed (pre-audit) incomes around the kink, with almost 5 times as many taxpayers in the bin around the kink as in the surrounding bins. This provides clear evidence of an overall taxable income response to taxation, which may reflect evasion, avoidance, or real responses. To isolate the evasion response, we turn to the distribution of post-audit income. Here we continue to see bunching, but to a smaller extent than for pre-audit income. The difference in bunching in the two distributions provides evidence of an evasion response to the marginal tax rate. The bunching that remains in the post-audit distribution reflects real responses and avoidance purged of the (detectable) evasion response.

\footnotetext{
${ }^{35}$ This distinction is relevant both because the efficiency implications of evasion and avoidance in general are not the same (Slemrod, 1995; Chetty, 2009), and because the evasion response to the marginal tax rate may provide a better understanding of the correct modeling of tax evasion and enforcement.
} 
Panel B shows the empirical distributions of pre-audit stock income (black curve) and postaudit stock income (grey curve) for all taxpayers in 2006 around the kink at 88,600 kroner (vertical line). ${ }^{36}$ As before, we consider a grouping individuals into 3000 kroner bins. For stock income, we find even stronger evidence of bunching, with about 10 times as many taxpayers in the bin around the kink point as in the surrounding bins. However, we see essentially no difference between the pre-audit and post-audit distributions, suggesting that the bunching effect reflects mostly avoidance and not (detectable) evasion. The view among tax inspectors at SKAT is that the strong bunching in stock income is driven almost exclusively by dividends from non-traded stock, which can be easily adjusted by owners of closely held corporations to achieve bunching. This type of response is indeed legal avoidance and not evasion.

Table 5 uses the bunching evidence to estimate elasticities of tax evasion and tax avoidance for self-employment income (Panel A) and stock income (Panel B). The first row in each panel shows the fraction of individuals bunching (defined as having an income within 1,500 kroner of the kink) among individuals within 40,000 kroner of the kink. The second row in each panel shows compensated elasticities using the method set out in Saez (2009). This method is based on comparing the actual distribution to a counterfactual distribution estimated by excluding observations in a band around the kink. The difference between the actual and counterfactual distributions gives an estimate of excess mass around the kink point, which can be compared to the size of the jump in the net-of-tax rate in order to infer the elasticity. The identifying assumption is that, in the absence of the discontinuous jump in tax rates, there would have been no spike in the density distribution at the kink. This assumption seems reasonable in light of the evidence in Figure 3, which would be hard to explain by anything other than the tax system. ${ }^{37}$

As shown in Table 5, the estimated elasticity of pre-audit taxable income for the selfemployed is equal to 0.14 , while the elasticity of post-audit taxable income equals 0.09 . The difference between the two is the compensated evasion elasticity with respect to the net-of-tax rate and is equal to 0.05. All of these estimates are strongly significant. For stock income,

\footnotetext{
${ }^{36}$ For married filers, the stock income tax is assessed jointly, and the bracket threshold in the figure is the one applying to such joint filers. For single filers, the bracket threshold is half as large at 44,300 kroner. We have aligned single and married filers in the figure by multiplying the stock income of singles by two.

${ }^{37}$ The assumption can be tested with several years of data and variation in the kink point over time. Chetty et al. (2009) show that the bunching at the top kink in the income tax moves closely with changes in the threshold level over the years 1994-2001. Similarly, Kleven and Schultz (2010) show that the bunching at the kink in the stock income tax moves closely with changes in that threshold over the years 1997-2005.
} 
elasticities are much larger. The elasticity of pre-audit stock income is about 2.24 and strongly significant. The elasticity of post-audit stock income is equal to 1.99, implying an elasticity of evasion equal to 0.25. However, this elasticity is not statistically significant. Finally, as discussed in Saez (2009), this estimation technique may be sensitive to the bandwidth around the kink used to estimate the elasticities, especially in situations where the clustering of taxpayers at the kink is not very tight. The last column of the table explores this possibility by considering a smaller sample around the kink. We find that the estimates are not very sensitive to bandwidth, and this is precisely because the bunching in the Danish tax data is so sharp.

To summarize these results, the marginal tax rate appears to have a small positive substitution effect on tax evasion for individuals with substantial self-reported income. Estimated evasion responses are much smaller than avoidance responses, although this decomposition is likely to be biased by the presence of undetected evasion that the method would attribute to avoidance. The combination of large evasion rates for self-reported income (as documented in the previous section) and small evasion effects of the marginal tax rate is not incompatible with economic theory as discussed in section 3. Importantly, the combined results from Section 5 and this section suggest that information reporting is much more important than low marginal tax rates to achieve enforcement.

\section{The Effects of Tax Enforcement on Evasion}

\subsection{Randomization Test}

In this section, we consider the effects of audits and threat-of-audit letters on subsequent reporting. We start by running a randomization test to ensure that the treatment and control groups are ex-ante identical in both experiments. Table 6 shows the results of the audit randomization in Panel A (columns (1)-(4)) and the letter randomization in Panel B (columns (5)-(8)). The table shows average incomes in different categories, percent of taxpayers with non-zero incomes in different categories, the share of females, and average age. Notice that we do not show self-employment income for the letter experiment, because this experiment was implemented only for employees (defined as those with no self-employment income). Unlike the baseline compliance study above, statistics are no longer estimated using population weights to match the full Danish population, but reflects instead the composition in the stratified random sample on which the experiments are based. We use experimental weights so as to increase 
slightly the power of our results. This is the reason why the statistics for the $100 \%$ audit group in column (1) are not the same as the statistics in Table 2.

For the audit randomization, income statistics are based on the tax returns filed in 2007 for the 2006 tax year, i.e. right before the baseline audits were implemented. We see that the differences between the $0 \%$ and $100 \%$ audit groups are always very small and never statistically significant at the $5 \%$ level, showing that the randomization was indeed successful. For the letter randomization, statistics are based on the pre-populated tax returns in 2008 with respect to the 2007 tax year, i.e. right before the letter experiment was implemented. ${ }^{38}$ Among the 14 statistics we report, only one difference (capital income) is statistically significant at the $5 \%$ level. Because we are looking are many statistics, it is not too surprising that at least one difference will be significant at the $5 \%$ level. Hence, it appears that the letter randomization was also successful.

\subsection{The Effect of Audits on Future Reporting}

It is useful to start by considering the effect of audits on future reporting in the context of the economic model of tax evasion developed in Section 3. In that model, reported income depends on the perceived probability of detection when engaging in tax evasion. Because tax audits are rare events for a taxpayer, experiencing an audit is likely to provide new information and therefore lead to a change in the perceived probability of detection. We may think of the detection probability as a product of two probabilities: the probability of audit and the probability of detection conditional on audit. Audits may affect the perceived detection probability through both channels. One would expect the effect on the perceived audit probability to be positive. The effect on the perceived probability of detection conditional on audit is ambiguous, because the taxpayer may learn that the tax administration is either more or less effective at uncovering evasion than expected. However, because of the way the audit procedure works (in the experiment and outside the experiment), it is most likely that the audits have a positive effect on the perceived probability of detection conditional on being audited. This is because audited

\footnotetext{
${ }^{38}$ More precisely, the statistics are based on the last version of the return before the letters were sent out. As the letters were distributed shortly after the pre-populated returns, the last return for most taxpayers was indeed the pre-populated return. However, a minor fraction of taxpayers (about 17\%) had already made self-reported adjustments to their returns in the short time window between pre-populated returns and letters. To get rid of the noise that this creates, we consider the effect of letters on adjustments to the latest return for each taxpayer at the time of receiving the letter, and hence the randomization test is based on this tax return concept.
} 
taxpayers are contacted only if tax inspectors upon examining the return believe that hidden income or unjustified deductions can potentially be uncovered. Hence, taxpayers are typically only aware of being audited in cases where tax inspectors are successful. Hence, the probability of detection conditional on audit (as well as the audit probability) is likely to increase as a result of experiencing an audit, in which case the standard economic model predicts an increase in reported income. In particular, we would expect to see increases in self-reported reported income, but not necessarily in third-reported income where the probability of detection is already close to one.

The few previous studies of the effect of audits on future reporting have not been able to identify a significant relationship between the two. These studies have considered either the TCMP audits described in section 2 (Long and Schwartz, 1987) or ordinary audits (Erard, 1992) in the United States. The problem with using TCMP audit variation is that taxpayers are aware that selection is random and that the audit is part of a special study. The problem with using ordinary audit variation is that selection is endogenous and it is very difficult to control for the ensuing selection bias in a convincing way. Our data contain more compelling variation based on randomized audit treatments, but where participants are not aware of the randomization.

As the experimental audits were implemented on tax returns filed in 2007, we estimate the effects of audits on subsequent reporting by comparing changes in filed income from 2007 to 2008 (income earned in 2006 and 2007, respectively) in the 0\% and 100\% audit groups. Table 7 shows estimates for the probabilities of increasing filed income (Panel A) and for the actual income changes (Panel B) for different income components. For panel B, income changes have been trimmed at $-200,000$ and $+200,000$ kroner in order to get rid of extreme observations that would make estimates very imprecise.Less than $2 \%$ of observations are trimmed on average.

Column (1) shows the audit adjustment in the $100 \%$ audit group in the baseline year, i.e. actual detected evasion. This column provides a useful benchmark against which we can compare the estimated effects of audits on future reporting. Actual detectable evasion can be seen as the amount of income that can be mechanically uncovered by a thorough tax audit, whereas the effect on subsequent reported income can be seen as the extra amount of income that can be recovered through a behavioral response to the perceived change in detection probability.

We start by considering the effect of audits on total reported income (columns (2) and (3)), 
and then break down the total effect into the effect on self-reported income (columns (4) and (5)) and the effect on third-party reported income (columns (6) and (7)). In each case, we show the year-ahead income change (i.e., probability of increase in Panel A, nominal amount of change in Panel B) for the 0\% audit group in the left column and the difference in year-ahead income changes between the $100 \%$ and $0 \%$ audit group in the right column.

For total net income and tax liability, we see that audits have a positive impact on subsequent reporting. The probability of increasing total net income and tax liability are almost 1 percentage point higher in the $100 \%$ audit group than in the $0 \%$ audit group. The tax liability estimate is statistically significant at the $5 \%$ level, while the net income estimate is marginally significant. The estimated effects on amounts are stronger. The effect on total net income is 2554 kroner, or $45 \%$ of the baseline audit adjustment in the $100 \%$ group, and the result is strongly significant at the $5 \%$ level. The effect on tax liability is 1377 kroner, corresponding to $55 \%$ of the baseline audit adjustment, and is also very significant. These results show that audits, in addition to mechanically increasing tax collection, generate substantial future tax revenue through behavioral responses to a higher perceived probability of detection.

Considering the effects on each subcomponent of income, we see that the effects of audits are generally positive with the only exception being a small negative (and statistically insignificant) effect on the probability of increasing capital income. However, the estimates for most of the subcomponents are quite small and several of them are statistically insignificant; only for selfemployment income is the effect large and statistically significant. Because self-employment income is almost fully self-reported, this suggests again that the informational setting is central to tax enforcement effects on compliance.

To explore the role of information, we split the effect on total income into the effect on thirdparty reported income and the effect on self-reported income in columns (4) to (7). For thirdparty reported income, estimated effects of audits are always small and statistically insignificant at the $5 \%$ level. This is also the case for the (small) part of self-employment income that is subject to third-party reporting. For self-reported income, a very different picture emerges. The effect on total net income is equal to 2322 kroner, corresponding to $91 \%$ of the total audit effect. The effect on self-employment income is equal to 1804 kroner and the effect on stock income is 633 kroner. All of these effects are strongly statistically significant. For the probability of increasing reported income, we find strong and statistically significant effects on total net 
income, self-employment income, and deductions, but not for stock income. For the remaining items, we do not detect any significant effects on amounts or probabilities.

We conclude that audits have significant and substantial effects on subsequent reporting of self-reported income, but negligible effects on the reporting of third-party income. This is consistent with the simple economic model presented in Section 3 if experiencing an audit raises the perceived probability of detection for self-reported items (where the probability is low initially) but not for third-party reported items (where the probability is close to one initially).

\subsection{The Effect of Threat-of-Audit Letters}

We now turn to the effect of the threat-of-audit letters, which provide exogenous variation in the probability of audit. ${ }^{39}$ As described above, the letters announce audit probabilities of either $50 \%$ or $100 \%$ to randomly selected taxpayers in the full-audit and no-audit groups. In interpreting the results, it is important to keep in mind that the probability of audit is not the same as the probability of detection, which is the parameter that ultimately determines tax compliance according to economic theory. The variation in the audit probability creates variation in the detection probability, with the size of the variation depending on the probability of detection conditional on being audited. The conditional probability of detection is unobservable, but is likely to be quite low for self-reported income where tax inspectors have little hard information to guide them in uncovering hidden income. Hence, while the audit probabilities being imposed in the experiment are extremely high, the detection probabilities are much more modest and the magnitude of the estimates should be interpreted in this light.

To study the effects of the threat-of-audit letters, we consider the sample of employees (as the letter randomization did not include self-employed individuals), who filed tax returns in both 2007 and 2008, and who have an address on record so that they could be reached by mail. Because taxpayers received the threat-of-audit letters shortly after receiving the pre-populated return (P-event) and about one month prior to the filing deadline (F-event) in 2008, we focus on the effect of letters on difference between the $\mathbf{P}$ - and $\mathbf{F}$-events in 2008 (for incomes earned in

\footnotetext{
${ }^{39}$ Besides the Minnesota tax experiment analyzed by Slemrod et al. (2001), audit-threat treatments have been considered in various non-tax contexts. In the development literature, Olken (2007) looks at the effect of audit threats on corruption in Indonesian village road projects. Recently, Fellner, Sausgruber, and Traxler (2009) consider the effect of audit threats on compliance with TV license fee rules. Broadly related, papers in the crime literature have studied the deterrence effect of policing in situations with quasi-random allocation of policy forces (e.g., Di Tella and Schargrodsky, 2004).
} 
2007). These are self-reported adjustments to the pre-populated return. As this return includes all third-party information available to the government, the estimates should be interpreted as effects on self-reported income.

To obtain sufficient statistical power, we focus on the probability of changing incomes on the pre-population return instead of effects on incomes per se. In general, and as can be seen in Table 7, t-statistics are always much lower for income changes than for the fraction of taxpayers changing income, because income amounts are widely dispersed and have large standard errors. This makes it easier to detect effects on probabilities than on amounts.

The estimates are shown in Table 8. Column (1) establishes a baseline by showing the probabilities of self-reported adjustments to the pre-populated return among those who did not receive a letter. Columns (2)-(4) then show estimated letter effects for the entire sample of employees (including both the $0 \%$ and $100 \%$ audit groups) and concerns the effect of receiving any letter (50\% and 100\% letters together). Column (2) reports the difference in adjustment probabilities between the letter and no-letter groups, while columns (3) and (4) split the total effect on adjustments into upward and downward adjustments. As in previous section, an upward (downward) adjustment is defined as an adjustment increasing (decreasing) net income and hence tax liability. As an adjustment is either upward or downward, column (2) is the sum of columns (3) and (4). The following three findings emerge.

First, there is a clear significant effect of threat-of-audit letters on the probability of selfreported income adjustments for almost all income components. For total net income, the probability increases by 1.65 percentage points from a base of $13.37 \%$, corresponding to an increase of $12.3 \%$. The effect is roughly similar for total tax paid. Interestingly, the effects of letters are relatively stronger for income items that are rarely adjusted such as personal income, capital income, and stock income. The percentage increase in adjustment probabilities $18.7 \%$ for personal income, $17.2 \%$ for capital income, $3.9 \%$ for deductions, and $51.5 \%$ for stock income. The small effect on deduction is statistically insignificant. Second, the effect of letters on adjustments reflect almost exclusively upward adjustments of taxable income for all income items. This is obviously consistent with the standard economic model: letters increase the perceived probability of detection and therefore deter taxpayers from underreporting. Third, the effect of letters on the probability of downward adjustment is close to zero for all income items, and none of the effects are statistically significant at the $5 \%$ level (only 1 of the 6 estimates 
have a t-statistic above 1$)$.

We now turn to the results in columns (5)-(10), which split the sample by $100 \%$ audit and $0 \%$ audit in the baseline year. The broad conclusion from these estimates is that letter effects tend to be stronger in the $0 \%$ audit group than in the $100 \%$ audit group. In particular, while the letter effects in the $100 \%$ audit group are mostly insignificant, the effects in the $0 \%$ audit group tend to be larger and most of them are statistically significant. Notice that this discrepancy between the two groups is consistent with our findings from the audit experiment discussed in the previous section. There we concluded that audits raise the perceived detection probability in the following year. This implies that, when the letter treatment is implemented in the year following the audits, the perceived probability of detection is already high among individuals in the $100 \%$ audit group. This effectively weakens the letter treatment and provides an explanation why effects are mostly insignificant in the $100 \%$ audit group.

For the $0 \%$ audit group, the percentage increase in the probability of any adjustment (columns $(5) /(1)$ ) is equal to $17.8 \%$ for total net income, $15.4 \%$ for total tax liability, $38.2 \%$ for personal income, $27.1 \%$ for capital income, $6.8 \%$ for deductions, and $48.5 \%$ for stock income. The effects on upward adjustments are generally larger for the $0 \%$ audit group than for the whole sample, and now all of the effects are statistically significant. Interestingly, for the $0 \%$ audit group, letters now appear to have a small positive effect on downward adjustments, although all except one (personal income) are still statistically insignificant. The presence of downward adjustments is incompatible with the simple model presented in Section 3, but can be understood by accounting for transaction costs associated with filing correctly. Filing correct tax returns is costly given the complexity of the tax code, which may lead to honest mistakes in both directions (under- and over-reporting). At the same time, if a return is not correct, the taxpayer faces potential transaction costs of subsequently having to deal with tax inspectors. ${ }^{40}$ Therefore, tax filers who receive audit threats will rationally spend more resources ensuring that the return is correct, which reduces filing errors in both directions and leads to a higher rate of both upward and downward adjustments.

Finally, columns (11) and (12) in Table 8 explore the differential impact of the $50 \%$ letter

\footnotetext{
${ }^{40}$ Consistent with this idea, the letters did generate complaints from tax filers who resented being chosen for this special audit study. Presumably, the complainers were honest tax filers who did not plan to deliberately evade taxes, because cheating tax filers would not have complained to SKAT for fear of the signal that this would send to tax inspectors.
} 
and $100 \%$ letter. Column (11) shows the difference in upward adjustment probabilities between the 50\%-letter and the no-letter groups, while column (12) shows the difference in upward adjustment probabilities between the 100\%-letter and 50\%-letter groups. We see a clear and consistent difference in the effects of the two types of letters, and the direction of the difference is consistent with the standard economic model. The differential impact of the $100 \%$ letter over the $50 \%$ letter tends to roughly similar to the impact of the $50 \%$ letter over no letter, implying that a $100 \%$ audit probability has about twice the effect of a $50 \%$ audit probability.

To summarize the results in this section, audit threats have significant and substantial effects on the probability of upward adjustments of self-reported income. This is especially true for the $0 \%$ audit group, consistent with the finding in the previous section that the $100 \%$ audit group has already reacted to the prior audit. The effect of a 100\% audit probability letter is about twice as large as the effect of a 50\% audit probability letter. These results are consistent with the simple economic model of evasion presented in Section 3.

\section{Conclusion}

The economics literature on tax evasion follows on the seminal work of Allingham and Sandmo (1972), who considers a situation where a taxpayer decides how much income to self-report facing a probability of audit and a penalty for cheating. Micro-simulations as well as laboratory experiments show that, at realistic levels of audit probabilities and penalties, an AS-type setting predicts much less compliance than we observe in practice, at least in developed countries. This suggests that the AS-model misses important aspects of the real-world reporting environment, and a number of different generalizations have been proposed and analyzed in the literature. In particular, several authors have argued that observed compliance levels can only be explained by accounting for psychological or cultural aspects of the reporting decision such as guilt, shame, and a moral obligation to pay taxes.

While we do not deny the importance of psychological and cultural aspects in the decision to evade on taxes, and indeed our results suggest that such factors may play a role, overall the evidence presented in this paper points to a more classic information story. In particular, we show that the key distinction in the taxpayer's reporting decision is whether income is subject to third-party reporting or if it is solely self-reported. Augmenting the AS-model with third-party reporting can account for most of our empirical findings. 
For self-reported income, our empirical results fit remarkably well with the basic AS-model: tax evasion is substantial and responds negatively to an increase in the perceived detection probability coming either from a prior audit or from a threat-of-audit letter. Interestingly, evidence from bunching at kink points shows that the elasticity of tax evasion with respect to the marginal tax rate is very modest relative to the elasticity of tax avoidance. This suggests that rigorous tax enforcement is a much more effective tool to combat tax evasion than lowering marginal tax rates.

For third party reported income, tax evasion is very modest and does not respond to perceived audit probabilities because the probability of detection is already very high due to systematic record matching. This shows that third-party reporting is an extremely effective enforcement device. Given the very costly nature of tax audits, we conclude that enforcement resources are better spent on third-party information reporting than on traditional audits of self-reported items. This also suggests that more work is needed in building a tax enforcement theory that centers on third-party reporting by firms (Kleven, Kreiner, and Saez, 2009) and to explore the role of firms in tax systems more generally (Gordon and Li, 2005; Kopczuk and Slemrod, 2006). 


\section{References}

Allingham, Michael G. and Agnar Sandmo (1972). "Income Tax Evasion: A Theoretical Analysis." Journal of Public Economics 1, 323-338.

Alm, James, Betty R. Jackson, and Michael McKee (1992a). "Estimating the Determinants of Taxpayer Compliance with Experimental Data." National Tax Journal 45, 107-114.

Alm, James, Betty R. Jackson, and Michael McKee (1992b). "Deterrence and Beyond: Toward a Kinder, Gentler IRS," in J. Slemrod (ed.), Why People Pay Taxes: Tax Compliance and Enforcement, University of Michigan Press: Ann Arbor, MI.

Alm, James, B. R. Jackson, and M. McKee (2008). "Getting the Word Out: Enforcement Information Dissemination and Compliance Behavior." Journal of Public Economics (in press). Alm, James, Gary H. McClelland, and William D. Schulze (1992). "Why Do People Pay Taxes?" Journal of Public Economics 48, 21-38.

Andreoni, James, Brian Erard, and J. Feinstein (1998). "Tax Compliance." Journal of Economic Literature 36, 818-860.

Beck, Paul J., Jon S. Davis, and Woon-Oh Jung (1991). "Experimental Evidence on Taxpayer Reporting under Uncertainty." Accounting Review 66, 535-558.

Becker, Gary S. (1968). "Crime and Punishment-An Economic Approach." Journal of Political Economy 76, 169-217.

Becker, Winfried, Heinz-Juergen Buchner, and Simon Sleeking (1987). "The Impact of Public Transfer Expenditures on Tax Evasion; an Experimental Approach." Journal of Public Economics 34, 243-252.

Beron, Kurt J., Helen V. Tauchen, and Ann D. Witte (1992). "The Effect of Audits and Socioeconomic Variables on Compliance," in J. Slemrod (ed.), Why People Pay Taxes: Tax Compliance and Enforcement, University of Michigan Press: Ann Arbor, MI.

Bloomquist, Kim M. (2003). "Tax Evasion, Income Inequality and Opportunity Costs of Compliance", 96th National Tax Association Conference.

Blumenthal, Marsha, Charles Christian, and Joel Slemrod (2001). "Do Normative Appeals Affect Tax Compliance? Evidence From a Controlled Experiment in Minnesota" National Tax Journal 54(1), 125-138.

Chetty, Raj (2009). "Is the Taxable Income Elasticity Sufficient to Calculate Deadweight Loss? The Implications of Evasion and Avoidance." American Economic Journal: Economic 
Policy 1, 31-52.

Chetty, Raj, John Friedman, Tore Olsen, and Luigi Pistaferri (2009). "Adjustment Costs, Firm Responses, and Labor Supply Elasticities: Evidence from Danish Tax Records." NBER Working Paper \#15617, December 2009.

Christian, Charles W. (1994). "Voluntary Compliance with the Individual Income Tax: Results from the 1988 TCMP Study." In the IRS Research Bulletin, 1993/1994, Publication 1500 (Rev. 9-94), 35-42. Internal Revenue Service, Washington, D.C.

Clotfelter, Charles T. (1983). "Tax Evasion and Tax Rates: An Analysis of Individual Returns," Review of Economics and Statistics 65(3), 363-73.

Cowell, Frank (1990). Cheating the Government. MIT Press, Cambridge, MA.

Di Tella, Rafael and Ernesto Schargrodsky (2004). "Do police reduce crime? Estimates using the allocation of police forces after a terrorist attack." American Economic Review 94, $115-133$.

Dubin, Jeffrey, Michael Graetz, Louis Wilde (1988). "An Empirical Analysis of Federal Income Tax Auditing and Compliance." National Tax Journal 41, 61-74.

Dubin, Jeffrey, Michael Graetz, Louis Wilde (1990). "The effect of audit rates on the federal individual income tax, 1977-1986." National Tax Journal 43, 395-409.

Erard, Brian (1992). "The Influence of Tax Audits on Reporting Behavior," in Joel Slemrod (ed.), Why people pay taxes: Tax compliance and enforcement. University of Michigan Press, Ann Arbor.

Feinstein, Jonathan (1991). "An Econometric Analysis of Income Tax Evasion and its Detection." Rand Journal of Economics 22, 14-35.

Feld, Lars P. and Bruno S. Frey (2002). "Trust Breeds Trust: How Taxpayers Are Treated." Economics of Governance 3, 87-99.

Feld, Lars P. and Bruno S. Frey (2006). "Tax Compliance as the Result of a Psychological Tax Contract: The Role of Incentives and Responsive Regulation." Institute for Empirical Research in Economics, University of Zurich, Working Paper No. 287, April 2006.

Feldman, Naomi and Joel Slemrod (2007). "Estimating Tax Noncompliance with Evidence from Unaudited Tax Returns," Economic Journal, March 2007, 327-352.

Fellner, Gerlinde, Rupert Sausgruber, and Christian Traxler (2009). "Testing Enforcement Strategies in the Field: Legal Threat, Moral Appeal and Social Information." Max Planck 
Institute for Research on Collective Goods, Working Paper 2009-3, September 2009.

Friedland, Nehemiah, Shlomo Maital, and Aryeh Rutenberg (1978). "A Simulation Study of Income Tax Evasion." Journal of Public Economics 10, 107-116.

Gordon, Roger and Wei Li (2005) "Tax Structure in Developing Countries: Many Puzzles and a Possible Explanation," NBER Working Paper No. 11661, forthcoming Journal of Public Economics.

Internal Revenue Service (1996). Federal Tax Compliance Research: Individual Income Tax Gap Estimates for 1985, 1988, and 1992, IRS Publication 1415 (Rev. 4-96), Washington, D.C. Internal Revenue Service (2006). Updated Estimates of the Tax Year 2001 Individual Income Tax Underreporting Gap. Overview, Washington, D.C.

Klepper, Steven and Daniel Nagin (1989). "The Anatomy of Tax Evasion," Journal of Law, Economics, and Organization 5(1), 1-24.

Kleven, Henrik, Claus Kreiner, and Emmanuel Saez (2009). "Why Can Modern Governments Tax So Much? An Agency Model of Firms as Fiscal Intermediaries." NBER Working Paper 15218, August 2009.

Kleven, Henrik and Esben Anton Schultz (2010). "Estimating Taxable Income Responses Using Danish Tax Reforms." Working Paper, 2010.

Kopczuk, Wojciech, and Joel Slemrod (2006). "Putting Firms into Optimal Tax Theory", American Economic Review: Papers and Proceedings 96(2), 130-134.

Long, Susan and Richard Schwartz (1987). "The Impact of IRS Audits on Taxpayer Compliance: A Field Experiment in Specific Deterrence." Paper presented at the annual meeting of the Law and Society Association, Washington, D.C.

Long, Susan, and Judyth Swingden (1990). "Third-Party Information Reporting and Compliance." In Research Conference Report, How Do We Affect Taxpayer Behavior?, Internal Revenue Service Document 7302 (3-91), Washington, D.C.

Olken, Benjamin (2007). "Monitoring Corruption: Evidence from a Field Experiment in Indonesia." Journal of Political Economy 115, 200-249.

Pommerehne, Werner W. and Bruno Frey (1992). "The Effects of Tax Administration on Tax Morale." Unpublished manuscript, University of Saarbrucken.

Saez, Emmanuel (2009). "Do Taxpayers Bunch at Kink Points?" American Economic Journal: Economic Policy (forthcoming). 
Sandmo, Agnar (2005). "The Theory of Tax Evasion: A Retrospective View." National Tax Journal 58, 643-63.

Shaw, Jonathan, Joel Slemrod, and John Whiting (2008). "Administration and Compliance." IFS Working Paper, forthcoming in Reforming the Tax System for the 21st Century: The Mirrlees Review.

Slemrod, Joel (1995). "Income Creation or Income Shifting? Behavioral Responses to the Tax Reform Act of 1986." American Economic Review Papers and Proceedings 85, 175-180.

Slemrod, Joel(2001). "A general model of the behavioral response to taxation," International Tax and Public Finance 8(2), 119-128.

Slemrod, Joel(2007). "Cheating Ourselves: The Economics of Tax Evasion," Journal of Economic Perspectives 21, Winter, 25-48.

Slemrod, Joel, Marsha Blumenthal, and Charles Christian (2001). "Taxpayer response to an increased probability of audit: evidence from a controlled experiment in Minnesota." Journal of Public Economics 79, 455-483.

Slemrod, Joel and Shlomo Yitzhaki (2002). "Tax avoidance, evasion and administration," in A.J. Auerbach and M. Feldstein (eds.), Handbook of Public Economics, Vol. 3, Elsevier: Amsterdam.

Yitzhaki, Shlomo (1974). "A Note on Income Tax Evasion: A Theoretical Analysis." Journal of Public Economics 3, 201-202.

Yitzhaki, Shlomo (1987), "On the excess burden of tax evasion", Public Finance Quarterly $15(2), 123-137$. 
Figure 1: Probability of Detection under Third-Party Reporting

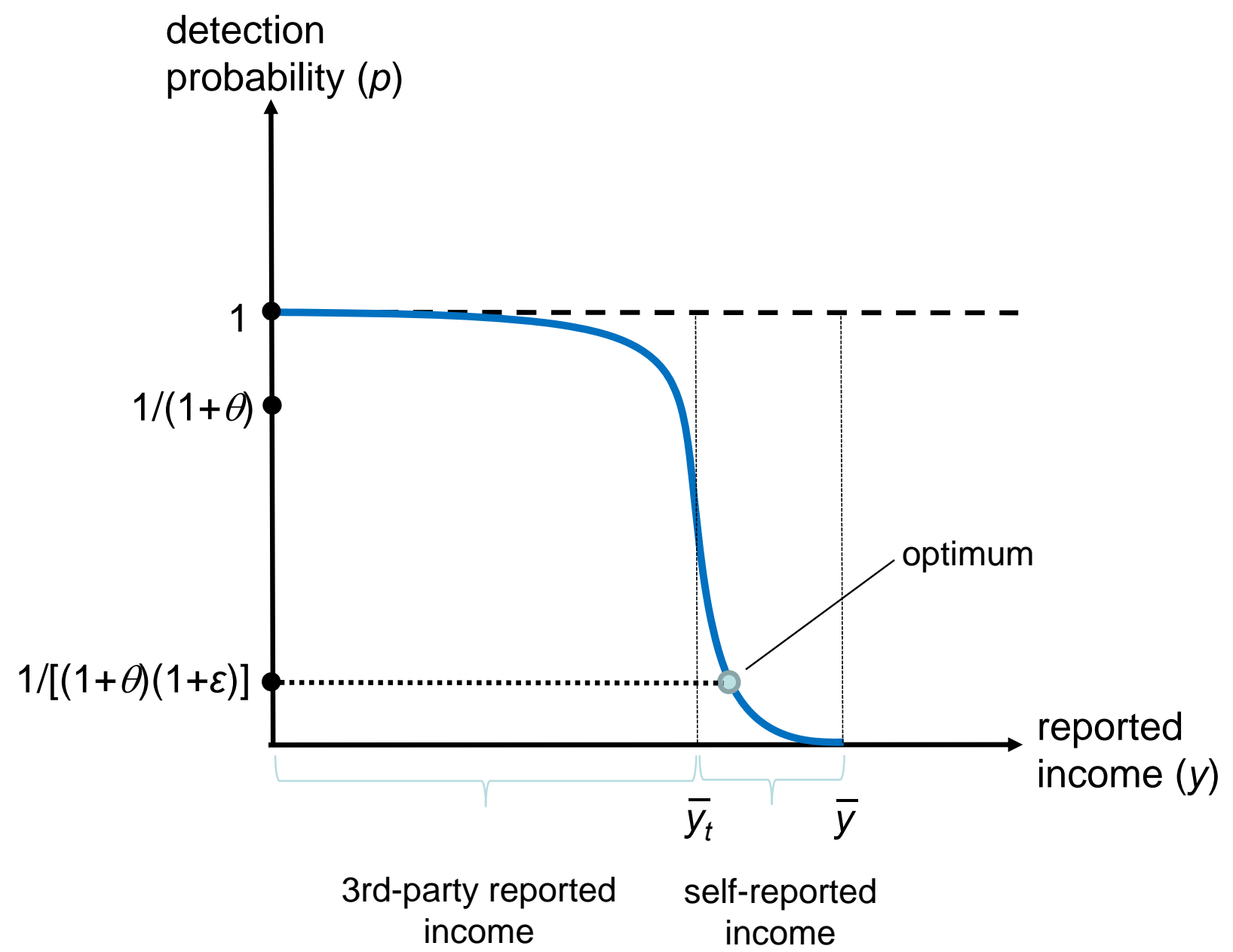




\section{Figure 2. Overview of Experimental Design}

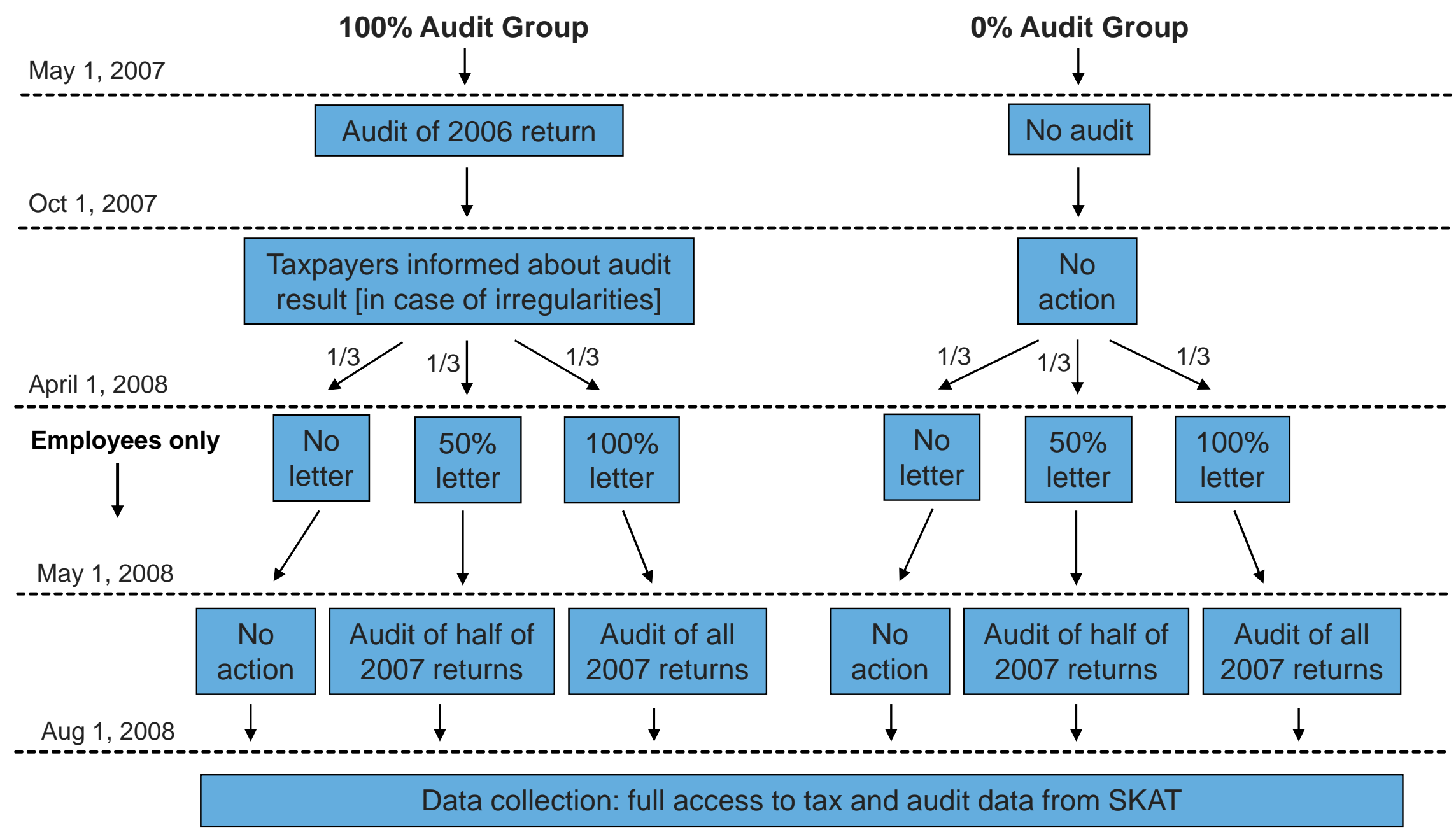



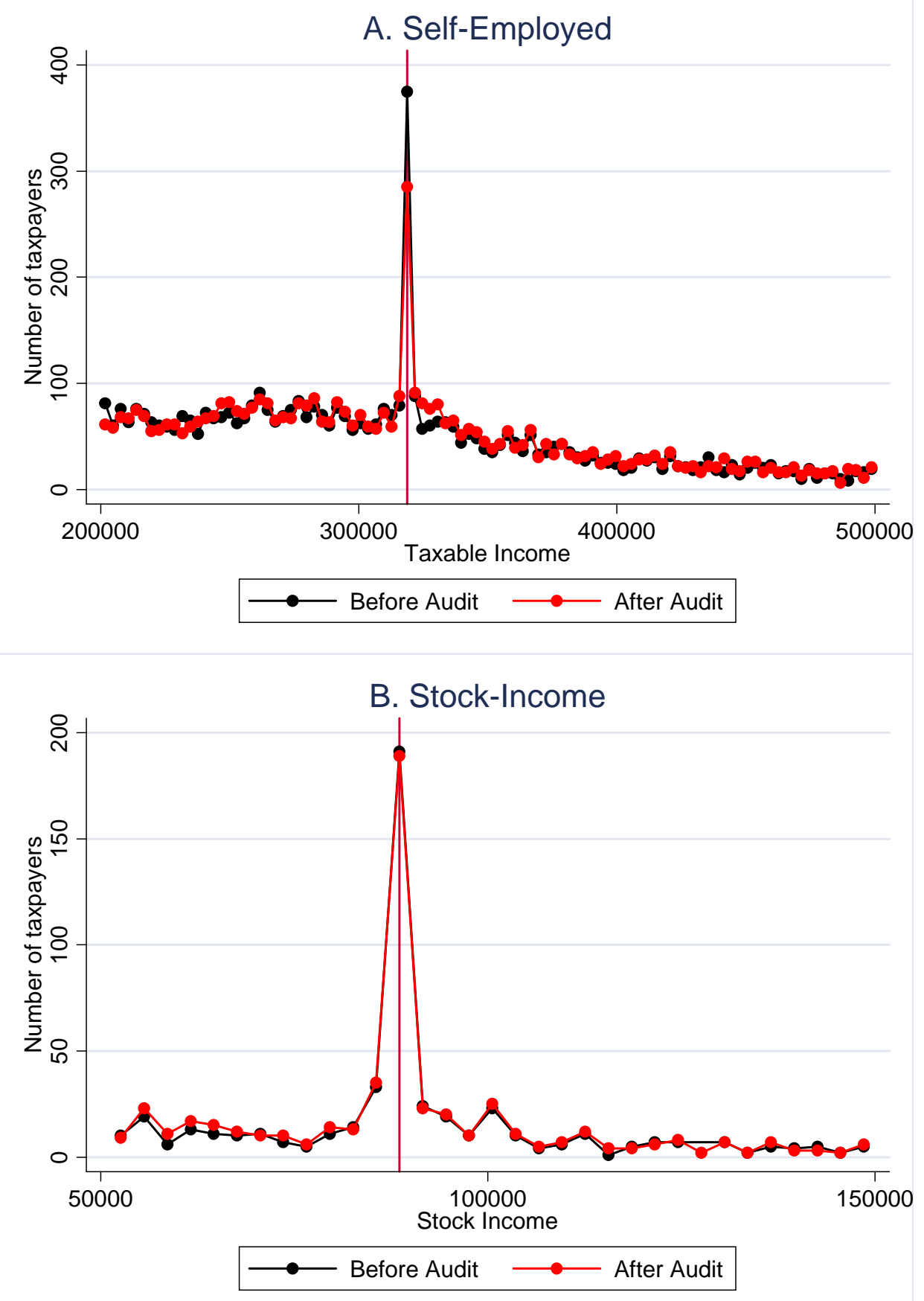

\section{Figure 3. Density Distributions around Kink Points}

The figure displays number of taxpayers (by 3000DKK bins) for taxable income for the self-employed (Panel A) and stock income (Panel B). In both panels, we report the series for incomes before audits (in black) and incomes after audits (in red) for the $100 \%$ audit group. The vertical line denotes the kink point where marginal tax rates jump. The jump is from $47 \%$ to $62 \%$ in panel A (top taxable income bracket) and from $28 \%$ to $43 \%$ in Panel B (top stock income bracket). In both cases, there is strong bunching at the kink which is evidence of behavioral responses to taxes. Bunching for pre-audit incomes captures both evasion and avoidance responses while bunching for after-audit income captures only avoidance response. Excess bunching for pre-audit incomes in panel A shows that there is a significant elasticity of evasion. 
Table 1. Danish Individual Income Tax in 2006

\section{A. Income Concepts}

Income Concept

(1) Labor Income

(2) Personal Income

(3) Capital Income

(4) Deductions

(5) Taxable Income

(6) Stock Income

\section{Definition}

Salary, wages, honoraria, fees, bonuses, fringe benefits, business earnings

Labor Income (1) + social transfers, grants, awards, gifts, received alimony - payroll tax, and certain pension contributions.

Interest income, rental income, business capital income - interest on debt (mortgage, bank loans, credit cards, student loans)

Commuting costs, union fees, unemployment contributions, other work related expenditures, charitable contributions, alimony paid

$=$ Personal income (2) + Capital income (3) - Deductions (4)

Dividends and realized capital gains from corporate stock

\section{B. Tax Rates and Tax Bases}

\begin{tabular}{llcr} 
Tax Type & Tax Base & Bracket (DKK) & Tax Rate \\
\hline (1) Payroll Tax & Labor Income & All income & $8.0 \%$ \\
(2) National Income Tax & Personal Income + max(Capital Income,0) & $38,500-265,500$ & $5.5 \%$ \\
& & $265,500-318,700$ & $11.0 \%$ \\
& & $318,700-$ & $26.5 \%[1]$ \\
(3) Regional Income Tax & Taxable Income & $38,500-$ & $32.6 \%[2]$ \\
(4) Stock Income Tax & Stock Income & $0-44,400$ & $28.0 \%$ \\
& & $44,400-$ & $43.0 \%$
\end{tabular}

Notes: All amounts in Danish kroner: US \$1 = 5.2 DKK as of January 2010.

[1]: the top rate is reduced so that the combined national and regional income top marginal tax rate never exceeds 59\%. The top marginal tax rate on labor income including the payroll tax is therefore $.08+.92^{\star} .59=62.3 \%$.

[2]: The regional tax includes municipal and county taxes in 2006. The rate shown is the average across all municipalities, and includes the optional church tax equal to $0.7 \%$.

[3]: The national and regional income taxes are based on individual income (not family income). The stock income tax is based on family income with brackets twice as large for married tax filers than those reported in the table. 
Table 2. Audit Adjustments Decomposition

\begin{tabular}{|c|c|c|c|c|c|c|c|c|c|}
\hline & \multicolumn{5}{|c|}{ A. Total income reported } & \multicolumn{4}{|c|}{ B. Third-party vs. self-reported income } \\
\hline & $\begin{array}{l}\text { Percentage } \\
\text { share of } \\
\text { population } \\
\end{array}$ & $\begin{array}{l}\text { Pre-audit } \\
\text { Income }\end{array}$ & $\begin{array}{c}\text { Audit } \\
\text { adjustment }\end{array}$ & $\begin{array}{l}\text { Under- } \\
\text { reporting }\end{array}$ & $\begin{array}{l}\text { Over- } \\
\text { reporting }\end{array}$ & $\begin{array}{l}\text { Third-party } \\
\text { income }\end{array}$ & $\begin{array}{l}\text { Third-party } \\
\text { under- } \\
\text { reporting }\end{array}$ & $\begin{array}{c}\text { Self- } \\
\text { reported } \\
\text { income }\end{array}$ & $\begin{array}{c}\text { Self-reported } \\
\text { under- } \\
\text { reporting } \\
\end{array}$ \\
\hline & $(1)$ & (2) & (3) & (4) & (5) & (6) & (7) & (8) & (9) \\
\hline \multicolumn{10}{|c|}{ Net Income and Total Tax } \\
\hline $\begin{array}{l}\text { Net Income } \\
\text { Total Tax }\end{array}$ & $\begin{array}{c}98.4 \\
(0.09) \\
90.8 \\
(0.21) \\
\end{array}$ & $\begin{array}{c}206,038 \\
(2,159) \\
69,940 \\
(1,142) \\
\end{array}$ & $\begin{array}{l}3,744 \\
(439) \\
1,670 \\
(223) \\
\end{array}$ & $\begin{array}{l}4,255 \\
(424) \\
1,782 \\
(222) \\
\end{array}$ & $\begin{array}{l}-511 \\
(132) \\
-112 \\
(21) \\
\end{array}$ & $\begin{array}{c}195,969 \\
(1,798)\end{array}$ & $\begin{array}{l}536 \\
(80)\end{array}$ & $\begin{array}{l}10,069 \\
(1,380)\end{array}$ & $\begin{array}{l}3,719 \\
(416)\end{array}$ \\
\hline \multicolumn{10}{|c|}{ Positive and Negative Income } \\
\hline $\begin{array}{l}\text { Positive Income } \\
\text { Negative Income }\end{array}$ & $\begin{array}{c}98.2 \\
(0.09) \\
79.1 \\
(0.29)\end{array}$ & $\begin{array}{c}243,984 \\
(2,511) \\
-37,946 \\
(1,014)\end{array}$ & $\begin{array}{l}3,449 \\
(437) \\
296 \\
(73)\end{array}$ & $\begin{array}{c}3,719 \\
(419) \\
536 \\
(53)\end{array}$ & $\begin{array}{l}-271 \\
(122) \\
-240 \\
(50)\end{array}$ & $\begin{array}{c}223,882 \\
(1,860) \\
-27,913 \\
(406)\end{array}$ & $\begin{array}{l}536 \\
(80)\end{array}$ & $\begin{array}{c}20,102 \\
(1,693) \\
-10,033 \\
(862)\end{array}$ & $\begin{array}{c}3,183 \\
(411) \\
536 \\
(53)\end{array}$ \\
\hline \multicolumn{10}{|c|}{ Income Components } \\
\hline Personal Income & $\begin{array}{c}95.2 \\
(0.15)\end{array}$ & $\begin{array}{c}209,681 \\
(1,473)\end{array}$ & $\begin{array}{l}2,343 \\
(402)\end{array}$ & $\begin{array}{l}2,472 \\
(401)\end{array}$ & $\begin{array}{l}-128 \\
(34)\end{array}$ & $\begin{array}{c}211,244 \\
(1,385)\end{array}$ & $\begin{array}{l}475 \\
(78)\end{array}$ & $\begin{array}{l}-1,563 \\
(540)\end{array}$ & $\begin{array}{l}1,997 \\
(393)\end{array}$ \\
\hline Capital Income & $\begin{array}{c}93.9 \\
(0.17)\end{array}$ & $\begin{array}{c}-11,075 \\
(340)\end{array}$ & $\begin{array}{c}156 \\
(160)\end{array}$ & $\begin{array}{l}335 \\
(56)\end{array}$ & $\begin{array}{l}-178 \\
(150)\end{array}$ & $\begin{array}{c}-14,556 \\
(602)\end{array}$ & $\begin{array}{l}33 \\
(7)\end{array}$ & $\begin{array}{l}3,481 \\
(542)\end{array}$ & $\begin{array}{l}302 \\
(55)\end{array}$ \\
\hline Deductions & $\begin{array}{c}60.1 \\
(0.35)\end{array}$ & $\begin{array}{c}-9,098 \\
(104)\end{array}$ & $\begin{array}{l}129 \\
(18)\end{array}$ & $\begin{array}{l}206 \\
(16)\end{array}$ & $\begin{array}{l}-77 \\
(10)\end{array}$ & $\begin{array}{c}-5,666 \\
(48)\end{array}$ & & $\begin{array}{c}-3,432 \\
(85)\end{array}$ & $\begin{array}{l}206 \\
(16)\end{array}$ \\
\hline Stock Income & $\begin{array}{c}22.5 \\
(0.30)\end{array}$ & $\begin{array}{c}5,635 \\
(1,405)\end{array}$ & $\begin{array}{l}274 \\
(48)\end{array}$ & $\begin{array}{l}308 \\
(46)\end{array}$ & $\begin{array}{l}-33 \\
(12)\end{array}$ & $\begin{array}{l}3,783 \\
(976)\end{array}$ & $\begin{array}{c}31 \\
(12)\end{array}$ & $\begin{array}{l}1,852 \\
(943)\end{array}$ & $\begin{array}{l}276 \\
(45)\end{array}$ \\
\hline Self-Employment & $\begin{array}{c}7.6 \\
(0.19)\end{array}$ & $\begin{array}{c}10,398 \\
(812)\end{array}$ & $\begin{array}{c}838 \\
(124)\end{array}$ & $\begin{array}{l}1,086 \\
(130)\end{array}$ & $\begin{array}{l}-248 \\
(60)\end{array}$ & $\begin{array}{l}1,164 \\
(177)\end{array}$ & $\begin{array}{l}10 \\
(4)\end{array}$ & $\begin{array}{l}9,234 \\
(816)\end{array}$ & $\begin{array}{l}1,075 \\
(130)\end{array}$ \\
\hline
\end{tabular}

Notes: Column (1) reports the percent of filers with non-zero pre-audit amounts in column (2). Columns (2) to (9) report amounts in Danish Kroner (US $\$ 1=$ DKK 5.2 as of 1/2010) and negative amounts are reported in negative. Column (2) displays income or tax reported before audits, column (3) displays the net audit adjustment, column (4) displays under-reporting in the audit adjustment (upward audit adjustments increasing tax liability), column (5) displays over-reporting in the audit adjustment (downward audit adjustments decreasing tax liability). Note that $(4)+(5)=(3)$. Column (6) displays third-party income, column (7) displays third-party income under-reporting (defined as upward audit adjustments in case where third party income is higher than final reported income for positive income items), column (8) displays self-reported income (defined as total reported income minus third-party reported income), column (9) displays self-reported income under-reporting (defined all upward audit adjustments net of third-party income under-reporting). Note that $(6)+(8)=(2)$ and $(7)+(9)=(4)$.

Top panel reports net income (sum of all positive income components minus all negative income components and other deductions) and total tax. Middle panel reports positive income (sum of all positive income components) and negative income (sum of all negative income components and deductions). Bottom panel displays various income components. Personal income is earnings, pensions, alimony, minus some retirement contributions. Capital income is interest income, returns on bonds, net rents, minus all interest payments. Deductions include work related expenses, union fees, charitable contributions, alimony paid, and various smaller items. Stock income includes dividends and realized capital gains on stocks. Self-employment income is net profits from unincorporated businesses. Net income is personal income, capital income, stock income, self-employment income, foreign income (not reported specifically), minus deductions.

All estimates are population weighted and based solely on the $100 \%$ audit group (19,680 observations). Standard errors are reported in parenthesis. 
Table 3. Audit Adjustments: Third-Party Reporting vs. Tax Withholding

\begin{tabular}{|c|c|c|c|}
\hline & $\begin{array}{l}\text { Third-party } \\
\text { income }\end{array}$ & $\begin{array}{c}\text { Third-party } \\
\text { under- } \\
\text { reporting }\end{array}$ & $\begin{array}{c}\text { Evasion rate } \\
(2) /(1)\end{array}$ \\
\hline & Amount & Amount & Percent \\
\hline & $(1)$ & $(2)$ & (3) \\
\hline \multicolumn{4}{|c|}{ A. Positive Income subject to Third-Party Reporting and Withholding } \\
\hline All items & $\begin{array}{c}216,801 \\
(1,616)\end{array}$ & $\begin{array}{l}400 \\
(75)\end{array}$ & 0.18 \\
\hline Earnings, Pensions, and Transfers & $\begin{array}{r}212,642 \\
(1,223)\end{array}$ & $\begin{array}{l}400 \\
(75)\end{array}$ & 0.19 \\
\hline $\begin{array}{l}\text { Other items } \\
=\text { all items minus Earnings, Pensions, Transfers }\end{array}$ & $\begin{array}{r}4,159 \\
(978)\end{array}$ & $\begin{array}{l}2 \\
(3)\end{array}$ & 0.05 \\
\hline \multicolumn{4}{|c|}{ B. Positive Income subject to Third-Party Reporting without Withholding } \\
\hline All items & $\begin{array}{r}7,081 \\
(769)\end{array}$ & $\begin{array}{l}148 \\
(26)\end{array}$ & 2.10 \\
\hline \multicolumn{4}{|c|}{$\begin{array}{l}\text { Notes: Column (1) displays third-party income amounts, column (2) displays third-party income under-reporting } \\
\text { (defined as upward audit adjustments in case where third party income is higher than final reported income for } \\
\text { positive income items). Column (3) is the evasion rate defined as (2)/(1). } \\
\text { Panel A presents results for positive income subject to both third-party reporting and tax withholding at source. It } \\
\text { first reports total such income and then divides such income between two categories (a) earnings, pensions, and } \\
\text { transfers (b) all other items. Panel B presents positive income subject to third-party reporting but without tax } \\
\text { withholding at source. } \\
\text { All estimates are population weighted. Amounts are in Danish Kroner (US } \$ 1=5.2 \text { DKK). Standard errors }\end{array}$} \\
\hline
\end{tabular}


Table 4. Probability of Audit Adjustments: Socio-economics vs. Tax Return Factors

\begin{tabular}{|c|c|c|c|c|c|c|c|c|c|c|}
\hline & \multicolumn{5}{|c|}{ A. Basic Variables } & \multicolumn{5}{|c|}{ B. Detailed Variables } \\
\hline & & $\begin{array}{l}\text { Social } \\
\text { factors }\end{array}$ & $\begin{array}{l}\text { Socio- } \\
\text { economic } \\
\text { factors }\end{array}$ & $\begin{array}{c}\text { Tax return } \\
\text { factors }\end{array}$ & All factors & & $\begin{array}{l}\text { Social } \\
\text { factors }\end{array}$ & $\begin{array}{c}\text { Socio- } \\
\text { economic } \\
\text { factors }\end{array}$ & $\begin{array}{l}\text { Tax return } \\
\text { factors }\end{array}$ & All factors \\
\hline & & $(1)$ & $(2)$ & (3) & (4) & & $(5)$ & (6) & $(7)$ & (8) \\
\hline Constant & & $\begin{array}{l}14.42 \\
(0.64)\end{array}$ & $\begin{array}{l}11.92 \\
(0.66)\end{array}$ & $\begin{array}{c}1.44 \\
(0.25)\end{array}$ & $\begin{array}{c}3.98 \\
(0.62)\end{array}$ & & $\begin{array}{l}9.16 \\
(0.85)\end{array}$ & $\begin{array}{c}6.68 \\
(0.95)\end{array}$ & $\begin{array}{c}0.23 \\
(0.82)\end{array}$ & $\begin{array}{c}1.55 \\
(1.10)\end{array}$ \\
\hline Female Dummy & & $\begin{array}{l}-5.76 \\
(0.43)\end{array}$ & $\begin{array}{l}-4.45 \\
(0.45)\end{array}$ & & $\begin{array}{l}-2.05 \\
(0.41)\end{array}$ & & $\begin{array}{l}-5.45 \\
(0.43)\end{array}$ & $\begin{array}{l}-3.76 \\
(0.46)\end{array}$ & & $\begin{array}{l}-1.88 \\
(0.43)\end{array}$ \\
\hline Married Dummy & & $\begin{array}{l}1.55 \\
(0.46)\end{array}$ & $\begin{array}{l}-0.36 \\
(0.48)\end{array}$ & & $\begin{array}{l}-1.64 \\
(0.44)\end{array}$ & & $\begin{array}{l}-0.71 \\
(0.49)\end{array}$ & $\begin{array}{l}-2.13 \\
(0.49)\end{array}$ & & $\begin{array}{l}-2.18 \\
(0.46)\end{array}$ \\
\hline Member of church & & $\begin{array}{l}-1.98 \\
(0.59)\end{array}$ & $\begin{array}{l}-2.67 \\
(0.58)\end{array}$ & & $\begin{array}{l}-1.19 \\
(0.54)\end{array}$ & & $\begin{array}{l}-1.91 \\
(0.59)\end{array}$ & $\begin{array}{l}-2.48 \\
(0.58)\end{array}$ & & $\begin{array}{l}-1.72 \\
(0.55)\end{array}$ \\
\hline Geographical Location & Copenhagen durmy & $\begin{array}{l}-0.29 \\
(0.67)\end{array}$ & $\begin{array}{l}1.20 \\
(0.67)\end{array}$ & & $\begin{array}{c}1.00 \\
(0.62)\end{array}$ & $\begin{array}{l}6 \text { location } \\
\text { dummies }\end{array}$ & $\begin{array}{l}\mathrm{p} \text {-value } \\
0.02\end{array}$ & $\begin{array}{l}\mathrm{p} \text {-value } \\
0.03\end{array}$ & & $\begin{array}{l}\mathrm{p} \text {-value } \\
1.72\end{array}$ \\
\hline Age & Age $>45$ durmy & $\begin{array}{l}-0.37 \\
(0.45)\end{array}$ & $\begin{array}{l}-0.35 \\
(0.45)\end{array}$ & & $\begin{array}{c}0.10 \\
(0.42)\end{array}$ & $\begin{array}{l}4 \text { age group } \\
\text { durmies }\end{array}$ & $\begin{array}{l}\mathrm{p} \text {-value } \\
0.00\end{array}$ & $\begin{array}{l}p \text {-value } \\
0.00\end{array}$ & & $\begin{array}{l}\mathrm{p} \text {-value } \\
17.59\end{array}$ \\
\hline Home Ownership & & & $\begin{array}{l}5.96 \\
(0.48)\end{array}$ & & $\begin{array}{l}-0.35 \\
(0.46)\end{array}$ & & & $\begin{array}{c}3.77 \\
(0.49)\end{array}$ & & $\begin{array}{l}-1.31 \\
(0.48)\end{array}$ \\
\hline Firm Size & Firm size<10 durmy & & $\begin{array}{c}4.43 \\
(0.82)\end{array}$ & & $\begin{array}{c}2.97 \\
(0.76)\end{array}$ & $\begin{array}{l}5 \text { firm size } \\
\text { durmmies }\end{array}$ & & $\begin{array}{c}p \text {-value } \\
0.00\end{array}$ & & $\begin{array}{l}\text { p-value } \\
0.00\end{array}$ \\
\hline Industrial Sector & Informal sector durmy & & $\begin{array}{l}3.25 \\
(0.86)\end{array}$ & & $\begin{array}{l}-0.99 \\
(0.79)\end{array}$ & $\begin{array}{l}22 \text { industry } \\
\text { durmies }\end{array}$ & & $\begin{array}{l}\text { p-value } \\
0.00\end{array}$ & & $\begin{array}{c}\mathrm{p} \text {-value } \\
0.00\end{array}$ \\
\hline Self-Reported Income Dummy & & & & $\begin{array}{c}9.47 \\
(0.53)\end{array}$ & $\begin{array}{c}9.72 \\
(0.54)\end{array}$ & & & & $\begin{array}{c}7.91 \\
(0.56)\end{array}$ & $\begin{array}{l}8.04 \\
(0.57)\end{array}$ \\
\hline (Self-Reported Income >20,000DKK) & & & & $\begin{array}{l}17.46 \\
(0.91)\end{array}$ & $\begin{array}{l}17.08 \\
(0.92)\end{array}$ & & & & $\begin{array}{c}9.51 \\
(1.07)\end{array}$ & $\begin{array}{c}8.56 \\
(1.07)\end{array}$ \\
\hline (Self-Reported Income $<-10,000 \mathrm{DKK}$ ) & & & & 14.63 & 14.53 & & & & $\begin{array}{l}14.15 \\
(0.71)\end{array}$ & $\begin{array}{l}13.72 \\
(0.72)\end{array}$ \\
\hline Auditing Flag Dummy & & & & 15.48 & 15.32 & & & & $\begin{array}{l}14.17 \\
(0.60)\end{array}$ & 14.23 \\
\hline Self-Employed Dummy & & & & & & & & & $\begin{array}{l}12.33 \\
(0.90)\end{array}$ & $\begin{array}{l}10.82 \\
(1.19)\end{array}$ \\
\hline Capital Income Dummy & & & & & & & & & $\begin{array}{c}0.61 \\
(0.84)\end{array}$ & $\begin{array}{l}1.04 \\
(0.87)\end{array}$ \\
\hline Stock Income Dummy & & & & & & & & & $\begin{array}{l}1.75 \\
(0.49)\end{array}$ & $\begin{array}{l}2.51 \\
(0.50)\end{array}$ \\
\hline Deduction Dummy & & & & & & & & & $\begin{array}{c}0.67 \\
(0.51)\end{array}$ & $\begin{array}{c}0.97 \\
(0.60)\end{array}$ \\
\hline Audit Adjustment in 2004 or 2005 Dummy & & & & & & & & & $\begin{array}{c}9.19 \\
(0.88)\end{array}$ & $\begin{array}{c}8.59 \\
(0.88)\end{array}$ \\
\hline Income controls & & & & & & $\begin{array}{l}6 \text { income } \\
\text { group dummies }\end{array}$ & & & $\begin{array}{l}p \text {-value } \\
0.00\end{array}$ & $\begin{array}{l}\mathrm{p} \text {-value } \\
0.00\end{array}$ \\
\hline R-square & & $1.07 \%$ & $2.14 \%$ & $17.14 \%$ & $17.44 \%$ & & $2.24 \%$ & $6.44 \%$ & $19.16 \%$ & $20.05 \%$ \\
\hline Adjusted R-square & & $1.04 \%$ & $2.10 \%$ & $17.13 \%$ & $17.39 \%$ & & $2.19 \%$ & $6.26 \%$ & $19.10 \%$ & $19.83 \%$ \\
\hline
\end{tabular}

Notes: This table reports coefficients of the OLS regression of an audit adjustment dummy on various dummy regressors. Bottom rows report the R-square and adjusted R-squares. All estimates are population weighted and based solely on the $100 \%$ audit group (19,680 observations). Standard errors reported in parenthesis. In Panel A (columns (1) to (4)), we include a basic set of dummy variables, while a richer set of variables is included in Panel B (columns (5) to (8)). In Panel B, we do not report the full set of coefficients for geographical, age, firm size, industrial sector, and income groups. We instead only report the $\mathrm{p}$-value from an F-test that the coefficients of those dummies are all equal to zero (for each category). The 6 location dummies are defined as Copenhagen, North Sealand, Middle and South Sealand, South Denmark, Middle Jutland, and North Jutland. The 4 age dummies are for age groups 0-25, 26-45, 46. $65,66+$. The 5 firm size dummies are for firms' size: 1, 2-10, 11-100, 101-1000, 1001+. The 6 income group dummies are for each of the bottom three quartiles separately, percentile 75 to 
Table 5. Tax Evasion vs. Tax Avoidance Elasticities

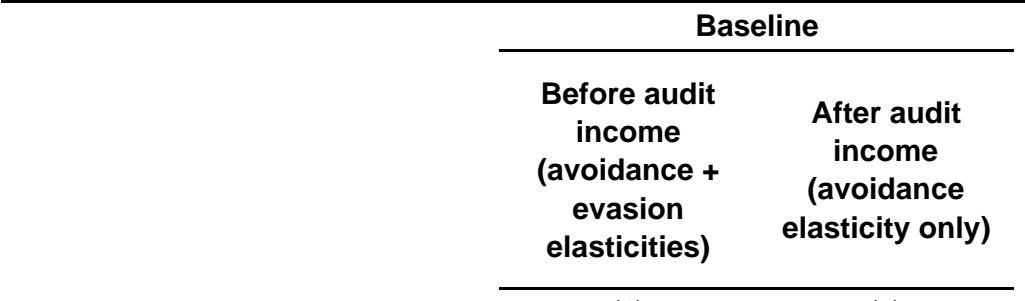

(1)

(2)

\begin{tabular}{cc}
\multicolumn{2}{c}{ Differences } \\
\hline $\begin{array}{c}\text { Robustness } \\
\text { (evasionce } \\
\text { check: } \\
\text { elasticity only) }\end{array}$ & $\begin{array}{c}\text { Difference using } \\
\text { smaller sample } \\
\text { around kink }\end{array}$ \\
\hline$(3)$ & $(4)$
\end{tabular}

(3)

$(4)$

$\begin{array}{lcccc}\text { A. Self-Employment Income (MTR jump from } & \mathbf{4 7 \%} \text { to } & \mathbf{6 2} \% \text { at } \mathbf{3 1 8 , 7 0 0} \text { DKK) } \\ \text { Fraction bunching (percent) } & 19.12 & 14.16 & 4.96 & 7.50 \\ & (0.90) & (0.79) & (1.20) & (1.85) \\ \text { Elasticity } & 0.161 & 0.103 & 0.058 & 0.056 \\ & (0.011) & (0.009) & (0.014) & (0.014) \\ \text { Number of observations } & 1,919 & 1,942 & 3,861 & 2,320\end{array}$

\section{B. Stock Income (MTR jump from $28 \%$ to $43 \%$ at 88,600 DKK)}

$\begin{array}{lcccc}\text { Fraction bunching (percent) } & 39.30 & 36.42 & 2.88 & 1.80 \\ & (2.22) & (2.11) & (3.06) & (3.69) \\ \text { Elasticity } & 2.243 & 1.996 & 0.247 & 0.120 \\ & (0.213) & (0.191) & (0.286) & (0.259) \\ \text { Number of observations } & 486 & 519 & 1,005 & 737\end{array}$

Notes: This table estimates the effects of marginal tax rates on tax evasion vs. tax avoidance using bunching evidence around kink points of the tax schedule where marginal tax rates jump. Panel A focuses on the self-employed and the top rate kink where marginal tax rates jump from $47 \%$ to $62 \%$ at 318,700 DKK. Panel B focuses on stock-income and the top rate kink for stockincome where marginal tax rates from 28 to $43 \%$ at 88,600 DKK for married filers and 44,300 DKK for single filers (we have aligned single filers by multiplying by two their stock income). As shown in Figure 2, in both cases, there is significant evidence of bunching at the kink both for income before audits and incomes after audits.

In each panel, the first row estimates the fraction of tax filers bunching (income within 1500 DKK of the kink) among tax filers with income within 40,000 DKK of the kink. Column (1) is for income before audit while column (2) is for income after audit. Column (3) reports the difference between column (1) and column (2). Column (4) presents a robustness check the difference when the sample is limited to tax filers within 20,000 DKK (instead of 40,000 DKK) of the kink.

In each panel, the second row estimates the (compensated) elasticity of reported income with respect to the net-of-tax rate using bunching evidence (following the method developed in Saez, 2009). Column (1) is the elasticity for before audit income while column (2) is the elascity for after audit income. Column (3) reports the difference between column (2) and column (1). Column (4) presents as a robustness check the difference in elasticities when the sample is limited to tax filers within 20,000 DKK (instead of $40,000 \mathrm{DKK}$ ) of the kink. The elasticity of before audit income combines both the evasion and avoidance elasticities while the elasticity of after audit income is the tax avoidance elasticity. Therefore, the difference in elasticities is the compensated elasticity of tax evasion with respect to the net-of-tax rate. 
Table 6. Randomization Checks: Audit and Letter experiments

\begin{tabular}{|c|c|c|c|c|c|c|c|c|}
\hline & \multicolumn{4}{|c|}{ A. Audit randomization } & \multicolumn{4}{|c|}{ B. Letter Randomization } \\
\hline & (1) & (2) & (3) & (4) & (5) & (6) & (7) & (8) \\
\hline Net Income & 265,069 & 263,485 & $-1,584$ & $(5,996)$ & 239,858 & 244,559 & 4,701 & $(3,415)$ \\
\hline Personal Income & 216,048 & 216,993 & 946 & $(2,345)$ & 255,923 & 258,842 & 2,918 & $(2,887)$ \\
\hline Capital Income & $-13,132$ & $-12,805$ & 327 & $(1,015)$ & $-16,647$ & $-15,439$ & 1,208 & $(532)$ \\
\hline Deductions & $-11,838$ & $-11,976$ & -138 & $(160)$ & $-8,364$ & $-8,287$ & 76 & $(159)$ \\
\hline Stock Income & 17,998 & 15,880 & $-2,118$ & $(4,869)$ & 7,656 & 8,101 & 445 & $(1,778)$ \\
\hline Self-Employment & 55,616 & 54,960 & -656 & $(2,869)$ & & & & \\
\hline$\%$ with Net Income & 99.55 & 99.52 & -0.03 & $(0.07)$ & 98.70 & 98.65 & -0.05 & $(0.15)$ \\
\hline$\%$ with Total Tax & 96.72 & 96.61 & -0.11 & $(0.17)$ & 96.61 & 96.27 & -0.34 & $(0.25)$ \\
\hline$\%$ with Personal Income & 94.87 & 94.73 & -0.14 & $(0.21)$ & 97.19 & 97.04 & -0.15 & $(0.23)$ \\
\hline \% with Capital Income & 95.67 & 95.40 & -0.27 & $(0.20)$ & 96.97 & 96.92 & -0.05 & $(0.23)$ \\
\hline \% with Deductions & 71.68 & 71.76 & 0.07 & $(0.44)$ & 64.22 & 64.48 & 0.26 & $(0.64)$ \\
\hline$\%$ with Stock Income & 40.30 & 40.23 & -0.07 & $(0.47)$ & 44.15 & 43.59 & -0.56 & $(0.67)$ \\
\hline$\%$ with Self-Employment & 40.18 & 40.37 & 0.19 & $(0.47)$ & & & & \\
\hline Number of observations & 23,148 & 19,630 & 42,778 & & 9,449 & 15,339 & 24,788 & \\
\hline
\end{tabular}

Notes: This table presents randomization checks for the audit experiment (panel A, cols. (1) to (4)) and the letter experiment (panel B, cols. (5) to (8)). Panel A compares baseline reported incomes in 2006 (before the audit experiment took place). Columns (1) and (2) present the baseline averages for the treatment group and control group respectively. Column (3) presents the difference between the treatment group and the control group. The standard error of the difference is presented in column (4). Panel B compares pre-populated tax returns for 2007 incomes before the letters are sent. The columns are constructed as in Panel A.

In panel B, the sample is restricted to tax filers with no self-employment in base year as the letter experiment was limited to tax filers with no self-employment income. Estimates are weighted according to the experiment stratification design. Weights do not reflect population weights. All the amounts are in Danish Kroner (US \$1 = DKK 5.2 as of 1/2010). 
Table 7. Effects of Prior Audits on Year to Year Income Changes

\begin{tabular}{|c|c|c|c|c|c|c|c|}
\hline & \multirow{3}{*}{$\begin{array}{c}\text { Baseline } \\
\begin{array}{c}\text { Audit adjustment in } \\
100 \% \text { audit group }\end{array} \\
(1)\end{array}$} & \multicolumn{2}{|c|}{ Total Income Change } & \multicolumn{2}{|c|}{ Self-Reported Income Change } & \multicolumn{2}{|c|}{ Third-Party Reported Income Change } \\
\hline & & $\begin{array}{l}\text { Increase in } 0 \% \text { audit } \\
\text { group }\end{array}$ & $\begin{array}{l}\text { Difference } 100 \% \text { audit } \\
\text { vs. } 0 \% \text { audit }\end{array}$ & $\begin{array}{l}\text { Increase in } 0 \% \text { audit } \\
\text { group }\end{array}$ & $\begin{array}{l}\text { Difference } 100 \% \text { audit } \\
\text { vs. } 0 \% \text { audit }\end{array}$ & $\begin{array}{l}\text { Increase in } 0 \% \text { audit } \\
\text { group }\end{array}$ & $\begin{array}{l}\text { Difference } 100 \% \text { audit } \\
\text { vs. } 0 \% \text { audit }\end{array}$ \\
\hline & & (2) & (3) & (4) & (5) & (6) & (7) \\
\hline \multicolumn{8}{|c|}{ A. Probability of Income Increase from 2006 to 2007 (percent) } \\
\hline Net Income & $\begin{array}{l}21.95 \\
(0.30)\end{array}$ & $\begin{array}{l}60.84 \\
(0.33)\end{array}$ & $\begin{array}{c}0.90 \\
(0.48)\end{array}$ & $\begin{array}{l}37.47 \\
(0.32)\end{array}$ & $\begin{array}{c}2.11 \\
(0.48)\end{array}$ & $\begin{array}{l}59.30 \\
(0.33)\end{array}$ & $\begin{array}{c}0.24 \\
(0.48)\end{array}$ \\
\hline Total Tax & $\begin{array}{l}21.41 \\
(0.29)\end{array}$ & $\begin{array}{l}56.14 \\
(0.33)\end{array}$ & $\begin{array}{c}0.99 \\
(0.49)\end{array}$ & & & & \\
\hline Personal Income & $\begin{array}{c}2.84 \\
(0.12)\end{array}$ & $\begin{array}{l}63.74 \\
(0.32)\end{array}$ & $\begin{array}{l}0.29 \\
(0.47)\end{array}$ & $\begin{array}{l}11.24 \\
(0.21)\end{array}$ & $\begin{array}{c}0.41 \\
(0.31)\end{array}$ & $\begin{array}{l}63.55 \\
(0.32)\end{array}$ & $\begin{array}{c}0.38 \\
(0.47)\end{array}$ \\
\hline Capital Income & $\begin{array}{l}4.24 \\
(0.14)\end{array}$ & $\begin{array}{l}44.55 \\
(0.33)\end{array}$ & $\begin{array}{l}-0.03 \\
(0.49)\end{array}$ & $\begin{array}{l}22.24 \\
(0.28)\end{array}$ & $\begin{array}{c}0.39 \\
(0.41)\end{array}$ & $\begin{array}{l}43.45 \\
(0.33)\end{array}$ & $\begin{array}{c}0.18 \\
(0.49)\end{array}$ \\
\hline Deductions & $\begin{array}{c}4.43 \\
(0.15)\end{array}$ & $\begin{array}{l}27.87 \\
(0.30)\end{array}$ & $\begin{array}{c}0.69 \\
(0.44)\end{array}$ & $\begin{array}{l}17.46 \\
(0.25)\end{array}$ & $\begin{array}{c}0.93 \\
(0.38)\end{array}$ & $\begin{array}{l}20.14 \\
(0.27)\end{array}$ & $\begin{array}{c}0.15 \\
(0.39)\end{array}$ \\
\hline Stock Income & $\begin{array}{l}1.64 \\
(0.09)\end{array}$ & $\begin{array}{l}23.67 \\
(0.28)\end{array}$ & $\begin{array}{l}0.53 \\
(0.42)\end{array}$ & $\begin{array}{l}5.44 \\
(0.15)\end{array}$ & $\begin{array}{c}0.19 \\
(0.22)\end{array}$ & $\begin{array}{l}23.24 \\
(0.28)\end{array}$ & $\begin{array}{l}0.39 \\
(0.42)\end{array}$ \\
\hline Self-Employment & $\begin{array}{l}14.49 \\
(0.25)\end{array}$ & $\begin{array}{l}20.19 \\
(0.27)\end{array}$ & $\begin{array}{l}1.62 \\
(0.40)\end{array}$ & $\begin{array}{l}20.20 \\
(0.27)\end{array}$ & $\begin{array}{l}1.53 \\
(0.40)\end{array}$ & $\begin{array}{c}3.46 \\
(0.12)\end{array}$ & $\begin{array}{l}0.13 \\
(0.18)\end{array}$ \\
\hline B. Amount of Ir & e Change from 2 & 6 to 2007 & & & & & \\
\hline Net Income & $\begin{array}{l}5629 \\
(497)\end{array}$ & $\begin{array}{l}4444 \\
(536)\end{array}$ & $\begin{array}{l}2554 \\
(787)\end{array}$ & $\begin{array}{l}1696 \\
(448)\end{array}$ & $\begin{array}{l}2322 \\
(658)\end{array}$ & $\begin{array}{l}2748 \\
(467)\end{array}$ & $\begin{array}{c}232 \\
(691)\end{array}$ \\
\hline Total Tax & $\begin{array}{l}2510 \\
(165)\end{array}$ & $\begin{array}{l}2013 \\
(319)\end{array}$ & $\begin{array}{l}1377 \\
(464)\end{array}$ & & & & \\
\hline Personal Income & $\begin{array}{l}592 \\
(147)\end{array}$ & $\begin{array}{l}7207 \\
(435)\end{array}$ & $\begin{array}{l}168 \\
(638)\end{array}$ & $\begin{array}{l}-442 \\
(190)\end{array}$ & $\begin{array}{l}-144 \\
(277)\end{array}$ & $\begin{array}{l}7649 \\
(410)\end{array}$ & $\begin{array}{l}313 \\
(604)\end{array}$ \\
\hline Capital Income & $\begin{array}{l}145 \\
(456)\end{array}$ & $\begin{array}{l}-3616 \\
(185)\end{array}$ & $\begin{array}{c}68 \\
(275)\end{array}$ & $\begin{array}{l}2575 \\
(207)\end{array}$ & $\begin{array}{l}-47 \\
(306)\end{array}$ & $\begin{array}{l}-6191 \\
(202)\end{array}$ & $\begin{array}{c}114 \\
(299)\end{array}$ \\
\hline Deductions & $\begin{array}{l}102 \\
(23)\end{array}$ & $\begin{array}{l}205 \\
(70)\end{array}$ & $\begin{array}{l}167 \\
(101)\end{array}$ & $\begin{array}{l}-145 \\
(70)\end{array}$ & $\begin{array}{l}107 \\
(101)\end{array}$ & $\begin{array}{l}350 \\
(23)\end{array}$ & $\begin{array}{c}60 \\
\text { (33) }\end{array}$ \\
\hline Stock Income & $\begin{array}{l}485 \\
(71)\end{array}$ & $\begin{array}{c}805 \\
(202)\end{array}$ & $\begin{array}{c}508 \\
(293)\end{array}$ & $\begin{array}{c}-88 \\
(165)\end{array}$ & $\begin{array}{c}633 \\
(237)\end{array}$ & $\begin{array}{c}893 \\
(133)\end{array}$ & $\begin{array}{l}-125 \\
(195)\end{array}$ \\
\hline Self-Employment & $\begin{array}{l}4287 \\
(286)\end{array}$ & $\begin{array}{c}71 \\
(387)\end{array}$ & $\begin{array}{l}1745 \\
(571)\end{array}$ & $\begin{array}{c}587 \\
(390)\end{array}$ & $\begin{array}{l}1804 \\
(579)\end{array}$ & $\begin{array}{l}-516 \\
(135)\end{array}$ & $\begin{array}{c}-59 \\
(204)\end{array}$ \\
\hline
\end{tabular}

Notes: This table reports the effects of prior-audits on income changes from 2006 to 2007. Panel A focuses on the probability of a (nominal) income increase while Panel B focuses on the amounts of income changes. Column (1) reports the fraction with an audit adjustment in the 100\% audit group in base year (Panel A) and the average amount of the audit adjustment in base year (Panel B). Columns (2) reports the fraction with an income increase from 2006 to 2007 (Panel A) or the average income increase from 2006 to 2007 (Panel B) for the 0\% audit group. Column (3) reports the difference between the 100\% audit group and the $0 \%$ audit group in the fraction with an income increase from 2006 to 2007 (Panel A) or the average income increase from 2006 to 2007 (Panel B). Each row corresponds to a given income items. The complete definition of each income item is given in Table 2. Columns (4)-(5) repeat the analysis of cols. (2)-(3) limited to self-reported incomes instead of total reported income. Columns (6)-(7) repeat the analysis limited to third-party reported incomes instead of total reported income.

All income items are estimated for the full sample (40,602 observations). Estimates are weighted according to the experiment stratification design. Weights do not reflect population weights. Standard errors are reported in parenthesis.

For panel B, all the amounts are in Danish Kroner (US $\$ 1=$ DKK 5.2 as of 1/2010). Income changes are trimmed at $-200,000$ DKK and 200,000 DKK. That is, income changes are defined as $\min (200000$, $\max$ (income in 2007-income in 2006,-200000). This is done to avoid extreme outcomes which make estimates very imprecise. Less than $2 \%$ of observations are trimmed on average. 
Table 8. Threat-of-Audit Letter Effects on Probability of Adjusting Reported Income (in percent)

\begin{tabular}{|c|c|c|c|c|c|c|c|c|c|c|c|c|}
\hline & \multirow{3}{*}{$\begin{array}{l}\text { No Letter Group } \\
\begin{array}{c}\text { Both } 0 \% \text { and } \\
100 \% \text { audit } \\
\text { groups } \\
\text { Baseline }\end{array}\end{array}$} & \multicolumn{9}{|c|}{ Differences Letter Group vs. No Letter Group } & \multirow{2}{*}{\multicolumn{2}{|c|}{$\begin{array}{c}\begin{array}{c}50 \% \text { Letter - } \\
\text { No letter } \\
50 \% \text { letter }\end{array} \\
\begin{array}{c}\text { Both } 0 \% \text { and } 100 \% \\
\text { audit groups }\end{array}\end{array}$}} \\
\hline & & \multicolumn{3}{|c|}{ Both $0 \%$ and $100 \%$ audit groups } & \multicolumn{3}{|c|}{$0 \%$ audit group only } & \multicolumn{3}{|c|}{$100 \%$ audit group only } & & \\
\hline & & $\begin{array}{c}\text { Any } \\
\text { Adjustment }\end{array}$ & $\begin{array}{c}\text { Upward } \\
\text { Adjustment }\end{array}$ & $\begin{array}{l}\text { Donnwward } \\
\text { Adjustment }\end{array}$ & $\begin{array}{c}\text { Any } \\
\text { Adjustment }\end{array}$ & $\begin{array}{c}\text { Upward } \\
\text { Adjustment }\end{array}$ & $\begin{array}{l}\text { Downward } \\
\text { Adjustment }\end{array}$ & $\begin{array}{c}\text { Any } \\
\text { Adjustment }\end{array}$ & $\begin{array}{c}\text { Upward } \\
\text { Adjustment }\end{array}$ & $\begin{array}{l}\text { Downward } \\
\text { Adjustment }\end{array}$ & $\begin{array}{c}\text { Upward } \\
\text { Adjustment }\end{array}$ & $\begin{array}{c}\text { Upward } \\
\text { Adjustment }\end{array}$ \\
\hline & (1) & $(2)$ & (3) & (4) & (5) & (6) & (7) & $(8)$ & (9) & $(10)$ & $(11)$ & $(12)$ \\
\hline Net Income & $\begin{array}{l}13.37 \\
(0.35)\end{array}$ & $\begin{array}{c}1.65 \\
(0.47)\end{array}$ & $\begin{array}{c}1.51 \\
(0.28)\end{array}$ & $\begin{array}{c}0.13 \\
(0.40)\end{array}$ & $\begin{array}{c}2.38 \\
(0.62)\end{array}$ & $\begin{array}{c}1.54 \\
(0.37)\end{array}$ & $\begin{array}{c}0.83 \\
(0.53)\end{array}$ & $\begin{array}{c}0.91 \\
(0.72)\end{array}$ & $\begin{array}{c}1.49 \\
(0.44)\end{array}$ & $\begin{array}{l}-0.57 \\
(0.61)\end{array}$ & $\begin{array}{c}1.04 \\
(0.33)\end{array}$ & $\begin{array}{c}0.95 \\
(0.33)\end{array}$ \\
\hline Total Tax & $\begin{array}{l}13.67 \\
(0.35)\end{array}$ & $\begin{array}{l}1.56 \\
(0.48)\end{array}$ & $\begin{array}{c}1.54 \\
(0.28)\end{array}$ & $\begin{array}{c}0.01 \\
(0.40)\end{array}$ & $\begin{array}{c}2.11 \\
(0.63)\end{array}$ & $\begin{array}{l}1.67 \\
(0.37)\end{array}$ & $\begin{array}{c}0.44 \\
(0.53)\end{array}$ & $\begin{array}{l}1.00 \\
(0.73)\end{array}$ & $\begin{array}{c}1.42 \\
(0.44)\end{array}$ & $\begin{array}{l}-0.41 \\
(0.61)\end{array}$ & $\begin{array}{c}0.99 \\
(0.33)\end{array}$ & $\begin{array}{l}1.10 \\
(0.33)\end{array}$ \\
\hline Personal Income & $\begin{array}{c}2.51 \\
(0.16)\end{array}$ & $\begin{array}{c}0.47 \\
(0.22)\end{array}$ & $\begin{array}{c}0.31 \\
(0.16)\end{array}$ & $\begin{array}{c}0.16 \\
(0.15)\end{array}$ & $\begin{array}{c}0.96 \\
(0.30)\end{array}$ & $\begin{array}{c}0.48 \\
(0.21)\end{array}$ & $\begin{array}{c}0.49 \\
(0.21)\end{array}$ & $\begin{array}{l}-0.01 \\
(0.34)\end{array}$ & $\begin{array}{c}0.14 \\
(0.25)\end{array}$ & $\begin{array}{l}-0.16 \\
(0.23)\end{array}$ & $\begin{array}{c}0.26 \\
(0.19)\end{array}$ & $\begin{array}{c}0.09 \\
(0.19)\end{array}$ \\
\hline Capital Income & $\begin{array}{c}4.43 \\
(0.21)\end{array}$ & $\begin{array}{c}0.76 \\
(0.29)\end{array}$ & $\begin{array}{c}0.76 \\
(0.24)\end{array}$ & $\begin{array}{l}-0.01 \\
(0.17)\end{array}$ & $\begin{array}{c}1.20 \\
(0.38)\end{array}$ & $\begin{array}{c}1.04 \\
(0.31)\end{array}$ & $\begin{array}{c}0.16 \\
(0.23)\end{array}$ & $\begin{array}{c}0.31 \\
(0.45)\end{array}$ & $\begin{array}{c}0.49 \\
(0.37)\end{array}$ & $\begin{array}{l}-0.18 \\
(0.26)\end{array}$ & $\begin{array}{c}0.52 \\
(0.28)\end{array}$ & $\begin{array}{c}0.48 \\
(0.28)\end{array}$ \\
\hline Deductions & $\begin{array}{c}9.00 \\
(0.29)\end{array}$ & $\begin{array}{c}0.35 \\
(0.39)\end{array}$ & $\begin{array}{c}0.28 \\
(0.08)\end{array}$ & $\begin{array}{c}0.07 \\
(0.38)\end{array}$ & $\begin{array}{c}0.61 \\
(0.51)\end{array}$ & $\begin{array}{c}0.35 \\
(0.10)\end{array}$ & $\begin{array}{c}0.26 \\
(0.50)\end{array}$ & $\begin{array}{c}0.09 \\
(0.60)\end{array}$ & $\begin{array}{c}0.22 \\
(0.13)\end{array}$ & $\begin{array}{l}-0.13 \\
(0.58)\end{array}$ & $\begin{array}{c}0.16 \\
(0.10)\end{array}$ & $\begin{array}{c}0.24 \\
(0.10)\end{array}$ \\
\hline Stock Income & $\begin{array}{c}1.32 \\
(0.12)\end{array}$ & $\begin{array}{c}0.68 \\
(0.18)\end{array}$ & $\begin{array}{c}0.64 \\
(0.16)\end{array}$ & $\begin{array}{c}0.04 \\
(0.08)\end{array}$ & $\begin{array}{c}0.64 \\
(0.23)\end{array}$ & $\begin{array}{c}0.48 \\
(0.20)\end{array}$ & $\begin{array}{c}0.16 \\
(0.10)\end{array}$ & $\begin{array}{c}0.71 \\
(0.28)\end{array}$ & $\begin{array}{c}0.80 \\
(0.25)\end{array}$ & $\begin{array}{l}-0.09 \\
(0.12)\end{array}$ & $\begin{array}{c}0.56 \\
(0.18)\end{array}$ & $\begin{array}{c}0.17 \\
(0.19)\end{array}$ \\
\hline Number of obs. & 9,449 & 24,788 & 24,788 & 24,788 & 14,145 & 14,145 & 14,145 & 10,643 & 10,643 & 10,643 & 24,788 & 24,788 \\
\hline
\end{tabular}

Notes: Column (1) reports the fraction (in percent) of tax filers which adjust a given income item (listed on the left hand side rows) among those did not receive the letter. For each income component listed on the left column (see footnote of Table 2 for complete definitions), the table reports the effects of letters on the probability that the tax filer adjusts the reported income when filing his/her income tax return. Column (2) reports the difference in fraction adjusting between the letter and no letter groups. Column (3) reports the difference in fraction adjusting upward while column (4) reports the difference in fraction adjusting downward ((3)+(4)=(2)). Cols. (5), (6), (7) repeat cols. (2), (3), (4) but limiting the sample to those not audited in base year (0\% audit group). Cols. (8), (9), (10) repeat cols. (2), (3), (4) but limiting the sample to those audited in base year (100\% audit group). Column (11) reports the difference in adjustments between the letter group with $50 \%$ audit probability and the no letter group. Column (12) reports the difference in adjustments between the letter group with $100 \%$ audit probability and the letter group with $50 \%$ audit probability.

The sample includes only tax filers who did not have any self-employment income in base year (as tax filers with self-employment income were not part of the letter experiment). Estimates are weighted according to the experiment stratification design. Weights do not reflect population weights. Standard errors are reported in parenthesis. 